\title{
ACCELERATED DEPRECIATION TAX BENEFITS IN UTILITY RATE MAKING
}

\author{
MAX SWIREN
}

I

N SECTION 167 of the Internal Revenue Code of 1954, the Congress authorized accelerated depreciation deductions in the computation of income tax in order to encourage plant expansion. The hearings, reports and debates reveal no consideration of the impact of such allowances upon the regulation of public utilities. With the absence of an authentic guide, a variety of conflicting theories have been evolved for determining the precise nature of the benefit inuring to utilities from the accelerated depreciation and the proper allocation of such benefits among investors and consumers, present and future.

The problem arises where a utility retains the straight line depreciation method for computing cost of service (as generally required in the uniform systems of account) while utilizing larger deductions, under an accelerated depreciation method, in computing federal income taxes. Were uniformity achieved by adopting accelerated depreciation for accounting as well as tax purposes, the problem would disappear. The adverse effect of such uniformity on income, however, would require substantial rate increases. No such procedure has been seriously considered.

Few aspects of public utility regulation fail to mirror an underlying social philosophy. The direction that regulation is permitted to take and the concept upon which it is predicated reflect the purpose, function and future we would accord private enterprise in this vital area of the economy. The tugging and pulling of competing philosophies is nowhere more manifest than in the debates and decisions with respect to the tax advantages derived from accelerated depreciation.

Provision for depreciation is designed to charge the revenues of an accounting period with the cost of equipment or facilities consumed during that period. Mr. Justice Brandeis has aptly noted that no accurate measure of plant consumption in any particular year has ever been devised. ${ }^{1}$ The almost universal method of handling this imponderable has been to spread equally, over the service life of a property, the cost, less the estimated salvage recovery. Criticism of the straight-line method has been based largely upon the conviction that during the early years of use, a facility's income-producing potential is greater, and its maintenance demands are less, than during the

$\dagger$ Member of the Illinois Bar.

1 United Rys. \& Elec. Co. v. West, 280 U.S. 234, 262 (1930) (dissenting opinion). 
later years of its service life. Various methods of computing accelerated depreciation have been formulated to match the earlier years of greater productivity with enhanced provisions for depreciation.

During World War II, certificates of necessity amortizing costs over sixty months for income tax purposes successfully induced the construction of urgent wartime facilities. This experience gave impetus to those who insisted that the treasury's tight-fisted limitations upon provisions for depreciation tended to retard capital investment. With the overhaul of the income tax system by the Congress, Section 167 of the Internal Revenue Code of 1954 authorized various methods of accelerated depreciation. In general, these accelerated methods are designed to charge against taxable income about two-thirds of the net cost of a property or facility during the first half of its useful life. The Congress anticipated that the more rapid recovery of investments out of income taxes would encourage the capital facility expansion required for the increasing growth of our national economy. 2

Unregulated industry found itself free to adopt an accelerated method of depreciation solely for the computation of federal income taxes, or for the determination of costs in pricing as well. The financial demands and competitive pressures experienced by a particular industry necessarily influenced its course of conduct. By and large, unregulated industry has seized the opportunity to apply accelerated depreciation methods to their normal accounts as well as to the computation of federal income taxes. An influencing consideration was the realization that price inflation, coupled with technological trends toward automation, tended materially to lift the level of replacement costs for which depreciation reserves were expected to provide. Some unregulated industries have elected to continue on their way, retaining straight-line depreciation for all purposes. Other firms have taken advantage of the rapid depreciation to lower federal income taxes in the initial years without charging an equivalent level for depreciation in their normal accounts.

Public utilities, operating as they do on a cost of service basis, confronted special problems. Rates of charge to utility consumers are designed fairly to cover the full cost of service including an appropriate return to investors. The high level of capital investment in public utilities makes charges for depreciation a sizeable item in operating expenses. Regulatory agencies have quite uniformly required provisions for depreciation to be computed on a straight-line basis. ${ }^{3}$ This method had been consistent with the procedure, although seldom identical with the amount, in the income tax computation until accelerated depreciation methods were authorized.

With the adoption of the 1954 Code, many utilities, being engaged in heavy construction, found it possible materially to reduce current income tax

2S. REP. No. 1622, 83d Cong., 2d Sess. 26 (1954); H.R. REP. No. 1337, 83d Cong., 2d Sess. 24 (1954).

3 See, e.g., $R e$ Commonwealth Edison Co., 24 P.U.R.3d 209 (IIl. C.C. 1958). 
payments by computing the income tax deduction for depreciation on an accelerated method. The impact of this procedure upon current tax payouts has been advantageously large in the case of airlines, with their rapid turnover of costly equipment, the electric power industry, whose phenomenal growth requires ever increasing construction of generating, transmission and distribution facilities, and the natural gas industry, which has been experiencing enormous expansion both in terms of geography and intensified use. There was raised at the outset the question of how the reduction in current tax payments should be recorded on the utility books of account and reflected in the rates of charge. That determination is interlaced with the problems of identifying and defining the benefits yielded by the use of accelerated depreciation for income tax purposes and allocating such benefits between consumers and investors.

The legislative history of Section 167 of the Code is specific only in evincing a congressional purpose to defer rather than to excuse the payment of taxes. So far as the committee reports and floor debates reveal, Congress was acting in terms of the economy as a whole, without any particular thought as to how public utility consumers and investors should share its benevolence. Regulatory concepts and accounting philosophy have stumbled on the roadblocks of competing self-interests. Two principal schools of thought have emerged, each with its own variations and limitations.

The differences in approach can quickly be seen from an illustrative example. Assume a public utility with the following operating results for a particular year:

Net income before Federal Income Taxes....

Federal Income Taxes actually paid........

Provision for Deferred Federal Income Taxes arising from the use of Accelerated Depreciation Deductions.

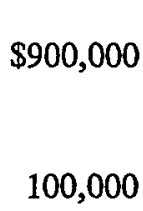

$\$ 2,000,000$

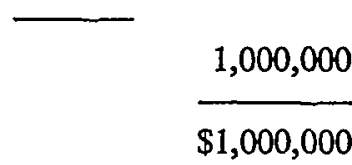

Net Income.......................

As set out, this is a normal application of reserve accounting principles, matching for the income of the current period the tax applicable thereto. The special deduction for the current tax payment, yielded by the enhanced depreciation deductions, is taken as a borrowing of those deductions from future years, and the reduction in tax payment is accumulated in a reserve to meet the tax payments when they arise in the future. Under this normalization method what is available for allocation among investors and ratepayers is an accumulated reserve for deferred federal income taxes, constituting, in effect, an interest-free fund of capital. 
The flow-through school of thought would seize for the ratepayer the entire reduction in current tax payments. They see the $\$ 100,000$ in the example as a permanent deferral or tax saving for which no provision need be made. Accordingly this amount would flow through to, and enhance, the net income against which the reasonableness of rates of charge to consumers would be measured.

\section{The Flow-ThRough TheORY}

Basically, flow-through is cash accounting. Only the current tax payment is recognized as an expense; no provision for any future tax is made. The assumption is that there will be a continuity of accelerated tax deductions flowing from utility growth at the same or increasing rates. Thus the increase in income taxes arising in the later years of service life of facilities (resulting from the declining depreciation deductions) will be paralleled by tax deductions (at the higher earlier life rates) with respect to subsequent property additions. Offsetting the latter against the former would render future cash tax payments unnecessary. If such offsets are assumed, the item is equated with a permanent tax deferral for which no provision need be made. The reduction in current tax payments is thus permitted to flow through to, and increase, the net income, immediately thereby tending towards lower rates of charge.

Originally, the accounting profession countenanced this theory as permissible, but that opinion was completely reversed in 1958.4 The Interstate Commerce Commission and the regulatory bodies in a number of jurisdictions have fully adopted flow-through. 5 Regulatory bodies in some states have evidenced approval, either applying the theory to some of the utilities or establishing a modified flow-through procedure. ${ }^{6}$

The public interest requires that utilities maintain their costs at the lowest level consistent with proper service to the consumer. Accordingly, if the flow-through theory is sound and the reduction in current taxes is a permanent saving, utilities should be required to utilize that procedure. Some states

\footnotetext{
4 Accounting Research Bulletin No. 44, issued by the Committee on Accounting Procedure of the American Institute of Accountants in October 1954, held that recognition may, but need not, be given to deferred taxes associated with accelerated depreciation. This bulletin was revised in July, 1958 to state that "where material amounts are involved, recognition of deferred income taxes in the general accounts is needed to obtain an equitable matching of costs and revenues and to avoid income distortion, even in those cases in which the payment of taxes is deferred for a relatively long period. ..." Accounting Research Bulletin No. 44 (revised), para. 7.

5 Colorado, District of Columbia, Idaho, Maine, New Hampshire, New Jersey, North Carolina, North Dakota, Ohio, Oregon, Pennsylvania, Washington, and West Virginia. Citations appear in the Appendix.

${ }^{6}$ Arizona (each utility to be considered separately), California (subject to review), Missouri (either practice permissible), New Mexico (gas and electric utilities only), New York (modified to permit sharing by stockholders) and Vermont (gas and electric utilities only). Citations appear in Appendix.
} 
that have embraced the flow-through theory have imposed that obligation.7

Among the less orthodox advocates of this theory there has been a recognition that flow-through may fail to provide for future obligations and, in all likelihood, the onus would fall upon the investors. The New York Commission has accordingly provided compensation for that risk in the form of a rather sizeable increase in the allowable rate of return. ${ }^{8}$ This raises an interesting question to those responsible for financial reporting since a current allowance is being made in earnings without accounting therefor.

Certain jurisdictions requiring flow-through when accelerated depreciation is adopted permit utilities to adhere or return to straight-line depreciation for income tax purposes. 9 Such Solomonic adjudication leaves the income tax payouts and expense at the high level produced by straight-line depreciation deductions and denies to either the rate-payer or the investor any of the advantages of the tax deferment.

\section{THE NORMALIZATION THEORY}

With respect to both the nature of the reduction in current income tax payments and the benefits derived therefrom, the normalization of taxes has emerged as an orderly, generally accepted accounting principle. Recognition is given to the fact that, over the service life of the property, the total amount of depreciation charged against taxable income is the same under straight-line and accelerated methods. Both require that the aggregate chargeoff over the service life of the facility be limited to its actual net cost; only the timing of the deductions during the service life is rearranged in the accelerated method. The theory gets its name from the procedure of normalizing the federal income tax expense so that it reflects the full income tax attributable to the taxable income for the current period. Accordingly, a charge to expense is made for income taxes deferred by the use of accelerated, rather than straight-line, depreciation charges in the computation of income taxes.

The provisions for deferred federal income taxes must be accumulated in a reserve which is reflected in the statement of assets and liabilities. For years in which the accelerated depreciation deduction drops below the straightline level, the resulting increase in income tax payments should be credited

7 See, e.g., Pennsylvania Pub. Util. Comm'n v. Manufacturers Light \& Heat Co., $33 \mathrm{~Pa}$. P.U.C. 669 (1956), aff'd, City of Pittsburgh v. Pub. Util. Comm'n, 182 Pa. Super. 551, 128 A.2d 372 (1956).

8 Re Central Hudson Gas \& Elec. Corp., 28 P.U.R.3d 317 (N.Y.P.S.C. 1959); Re Niagara Mohawk Power Corp. 28 P.U.R.3d 171 (N.Y.P.S.C. 1959). $C f$. Re Northern Natural Gas, Opinion No. 342 (March 7, 1961) where the Federal Power Commission approved normalization but allowed the investors a return of $11 / 2 \%$ on the capital component consisting of the accumulated reserve for deferred federal taxes.

9 Re Piedmont Natural Gas Co. 34 P.U.R.3d 1 (No. Car. Util. Comm'n 1960); Re Housatonic Pub. Serv. Co., 22 P.U.R.3d 1 (Conn. P.U.C. 1958); $R e$ Tax Treatment of Accelerated Depreciation, 33 P.U.R.3d 209 (Cal. P.U.C. 1960). 
to the income account (so as to reduce and normalize the expense) and charged against this reserve.

The normalization concept recognizes that the taxpayer is receiving an interest-free loan from the Treasury. To the extent that the taxes are deferred, the amounts represented thereby may be used by the taxpayer without interest charge until the inexorable reduction in depreciation charges brings about payment of the deferred amounts.

The better opinion is that the interest-free capital should inure to the benefit of the ratepayer. Cost of capital, both debt and equity, is a reimbursable expense to be recovered by revenues yielded by proper rates of charge. When costs of capital rise or fall, the revenue level which rates of charge must be fashioned to produce requires appropriate adjustment. By the same token, where capital is provided by the federal government without cost, the shareholder is not entitled to impose a charge for money-cost upon the consumer. Indeed, that has been the universal principle with respect to contributions of aid 10 and no substantive difference between that item and a free government loan can be discerned. Both investors and consumers share in the enhanced stability and the improved competitive position in the financial markets derived from an increasing fund of interest-free capital.

A number of utility managements have, in various forms, laid claim to the fund of capital accumulated in the reserve. As will presently be noted, some have insisted that the reserve be treated as a component of capital upon which a full return may be earned. Others have sought a lesser rate of return on so much of the plant as might be attributable to capital supplied by the reserve. The extent to which these claims have been resolved is considered more fully below.

\section{NATURE OF THE BENEFTt OR SAVING}

To evaluate the competing theories, it is necessary to define the precise benefit or saving yielded by the use of accelerated depreciation methods in the computation of federal income taxes. This in turn requires an understanding of the function of depreciation.

The uniform system of accounts, approved by the Federal Power Commission and generally adopted by the state bodies, defines depreciation as "the loss in service value not restored by current maintenance incurred in connection with the consumption or prospective retirement of utility plant in the course of service from causes which are known to be in current operation and against which the utility is not protected by insurance."11

${ }^{10} \operatorname{Re}$ Mondovi Tel. Co., (Wis. R.R. Comm. 1931C P.U.R. 439) (per Lilienthal, C.). See SpurR, 2 Guming Principles of Regulation 138 (1946). There is some analogy in Hope, where the Supreme Court sustained the refusal of FPC to recognize as a capital investment drilling costs charged to operating expenses long prior to regulation. FPC v. Hope Natural Gas Co., 329 U.S. 591, 598-99 (1944).

111 FED. REG. 811 (1936). 
Periodic charges for depreciation, made in the income accounts during the life of a property, provide recovery of the original cost of that property less realizable salvage. The straight-line method of depreciation arbitrarily assigns to each year or accounting period during the service life an equal pro-rata portion of the net cost. This is hardly an accurate measure of the consumption during each year or accounting period, but the straight-line method has the advantage of simplicity of computation and administration. With the advent of the Internal Revenue Code of 1954, most public utilities turned to accelerated depreciation for income tax purposes, while adhering to straight-line depreciation for corporate accounts and rate-making. Had an accelerated depreciation method been adopted for all purposes, a monumental increase in costs would be recorded and a compensatory increase in revenue and rates would be required.

Section 167 of the Code conferred upon the taxpayer the option of using specific methods of liberalized or accelerated depreciation in computing deduction for income tax purposes. The permissible accelerated methods enable the taxpayer to take, during the first half of the service life of the property, as much as two-thirds to three-fourths of the cost as a tax deduction. During the second half of the service life, the aggregate depreciation charges against taxable income would aggregate only one-fourth to one-third of the cost. Being limited to the net cost of the property, the aggregate depreciation charges against taxable income remain the same whether the straight-line or an accelerated method is used. Similarly, the total income taxes to be paid over the service life of the property will be the same, assuming no change in the tax rate. By its terms and its legislative history, the statute is designed to alter the timing but not the amount of tax payments.

The legislative intent of section 167, as revealed by the President's Budget Message12 and the reports of the House and Senate committees, ${ }^{13}$ was to permit postponement of income tax payments as an incentive to enhance capital investment. Faster recovery of investment through allowances against taxable income was selected as a means of stimulating economic growth. The incentive would stimulate financing for capital investment, provide more jobs, improve the standard of living and thus promote the national economy.

The key to the congressional thinking appears in the following paragraph contained in the Committee Reports of both Houses:

More liberal depreciation allowances are anticipated to have far-reaching economic effects. The incentives resulting from the changes are well timed to help maintain the present high level of investment in plant and equipment. The acceleration in the speed of the tax-free recovery of costs is of critical importance in the decision of management to incur risk. The faster tax writeoff would increase available

12 President's Budget Message, 1 U.S. Code CoNG. \& AD. NEws 1557, 1567 (1954).

13 S. REp. No. 1622, 83d Cong., 2d Sess. 26 (1954); H.R. REP. No. 1337, 83d Cong., 2d Sess. 24 (1954). 
working capital and materially aid growing businesses in the financing of their expansion. For all segments of the American economy, liberalized depreciation policies should assist modernization and expansion of industrial capacity, with resulting economic growth, increased production, and a higher standard of living. ${ }^{14}$

Both the President and the Congress made it clear that the incentive they were providing was a postponement of federal income taxes. Not the slightest suggestion of a permanent saving appears in any part of the legislative history. The Budget Message explained the proposed liberalized depreciation in these words: "Faster depreciation, it should be noted, will merely shift the tax deductions from later to earlier years. It will not increase total deductions."

The Report of the House Committee noted that the liberalized depreciation would "merely affect the timing and not the ultimate amount of depreciation deductions with respect to a property."15 In summarizing the effect of the measures proposed, the Report (p. 3) lists depreciation as one of the "Items Which Merely Shift the Deduction of Income between Taxable Years."

The floor debates produced comments identical with those in the committee reports. The absence of any intent to reduce income taxes is abundantly clear. Any reduction in the tax revenues received by the government in the years immediately following the statutory enactment would be compensated by correspondingly higher tax revenues in subsequent years, augmented by taxes attributable to a more rapidly expanding economy. No industry was singled out for special consideration, nor does there appear to have been any consideration of how the respective interests of the investor and the consumer would fare in the advantages conferred upon public utilities.

\section{Rationale of Competing Accounting Theories}

The accounting treatment must necessarily be related to the nature of the incentive that the Congress created in section 167. In those cases where accelerated tax depreciation is not a fair measure of depreciation costs currently recoverable in rates (as where straight-line depreciation is charged in rate-making), deferred tax accounting is required. As was intended, the statute furnished a tax deferral affording interest-free capital during the period that payment is postponed. The normalization accounting principle gives effect to that tax deferral. The flow-through theory that the enhanced depreciation allowances under a liberalized method give rise to a permanent tax saving has no relation to the terms or legislative history of section 167 .

The permanent saving theory rests upon an expectation that the utility will, through continuous growth at the present or an accelerated rate, generate tax deferrals from future acquisitions equal to or exceeding the enhanced tax payments arising during the latter service life of current additions. That the additional income taxes will have to be paid during the second half of

14 Ibid.

15 H.R. REP., op. cit. supra note 13. 
the service life of this year's acquisitions can hardly be denied. The argument is that there is no present liability and that additions from future acquisitions in a growth company will avoid a net increase in cash payouts for taxes in the future. Hence, it is reasoned that no reserve is actually necessary and no provision need be made. Such reasoning assumes a continuing or accelerating rate of growth-a circumstance that is hardly universal for utilities as a whole. Nor does it square with the basic considerations of reserve accounting. The reasoning would be equally applicable to charges for depreciation or provisions for pensions, neither of which is a present liability, in strict legal terms. In the sense of cash payouts and, so far as can now be foretold, in the likelihood that charges will never be less than credits, the depreciation and pension reserves are "permanent." In any growth enterprise, new property additions exceed the amount by which old property depreciates. Yet no one would dare propose elimination of depreciation reserve or the disregard of a depreciation charge in the income account.

The truth of the matter is that there is a strong inclination toward cash accounting where the problems of reserve accounting are complex and reach far into the future. Dealing in cash received and cash paid out has a special appeal to lawyers who so largely populate the regulatory agencies and whose normal familiarity with the functions and adaptability of reserve accounting is seldom comprehensive.

The public utility industry was the special victim of misguided theories with respect to depreciation. Until the depression brought stark reality to the industry, it was confidently assumed by a large segment of the utility industry and regulatory bodies that the retirement, or perhaps the retirement reserve, method would suffice.16 No systematic procedure to reflect the full consumption of property in the income accounts for the current period and no reserve to measure the accrued consumption in the property accounts were deemed necessary. The distorted accounts, the overstatement of income, and the undermining of confidence yielded dire results for utilities. The inadequacy and misuse of retirement reserve accounting that preceded sound depreciation accounting "opened the way to financial ruin." 17 It would be ironic were that devastating experience repeated because of a regulatory or judicial assumption that the cash requirements in the future to pay deferred tax expense allocable to current periods will be offset by other items of tax deduction from other properties.

16 The retirement reserve method, authorized by the Uniform System of Accounts for Electric Utilities, in 1922, was designed to spread the estimated retirement loss of "important retirements . . . but with due regard for amount of earnings available for this purpose in each year." [1943-44] National Association OF RAILROAD AND UTILITIES Commissioners (N.A.R.U.C.), REPORTS OF COMMISSION ON DEPRECIATION 17.

17 N.A.R.U.C., Report of Special Committee on Depreciation (November 15-19, 1938). See also Final Report of the Federal Trade Commission, S. Doc. No. 92, 70th Cong., 1st Sess. Part 72A, pp. 496-512, Part 84A, pp. 354-55, 498-506 (1935). 
Similarly, although pensions for the present working force are not payable until the future (often 40 years away), periodic estimates of additions to pension liability are made, charged as current expense, and added to a fund or reserve. The cash payouts are much smaller in amount than the current charges to expense and, with both inflation and growth, that circumstance is not likely to change in the foreseeable future. The pension fund will continue to grow and new appropriations will more than offset future payouts. Yet the need for funding is so uniformly recognized that Congress has made special provisions to encourage and facilitate the funding of accruals for prior years. 18

That current tax payments do not measure the tax expense for the current period is not a novel notion nor is it limited to this subject. For tax purposes, the income on installment sales is deferred until collection is actually made. This would result in an overstatement of income for the period of sale if the lesser current tax payments resulting from the deferral of income were treated as the measure of the current expense. Accordingly, good accounting practice requires that the tax on installment sale income ordinarily be recognized in the period of sale, even though no tax liability is created nor are payments due until subsequent years and may then be offset by losses or other items. Other situations illustrative of the differences that may arise between current income tax payments and the income tax allocable to the taxable income for the current period include (1) prepaid income taxable during the period of receipt but normally spread over future earnings periods, such as prepaid rent and unearned finance charges, (2) estimated renegotiation refunds, normally reported as a current expense but recognized as a deduction from taxable income only when determined, (3) unamortized discount in refunded bonds, currently deducted for income tax purposes but amortized in the accounts over the life of the refunded issue, and (4) reserves currently established for unrealized losses in book value which may not be written off for tax purposes until future periods.

Offsetting future tax maturities by added deferrals is not unlike refunding of bonds. Utilities are continually borrowing money to provide for expansion as well as to refund bonds, as they fall due. With added and refunded bond issues, the debt appears to perpetuate itself. Yet no one would defend eliminating that "perpetual liability" from the accounts of a utility.

Taken individually, or as a whole, the property additions for a particular year may well provide larger than normal depreciation deductions for tax purposes that year and in the immediate future, and commensurately less than normal deductions and higher income taxes in the later service life. This process is inexorable. That it will be paralleled by added tax deferrals attributable to additions in future years does not erase the reality of the taxes, currently deferred, which must be met in the future.

18 INT. Rev. CODE OF 1954, § 404(a)(1)(B). 
Borrowing depreciation credits from future years to apply against current taxable income depletes the credit of those future years and defers until then the payment for income tax measured by the borrowed credits.

Another aspect of the problem relates to value. Assets that have lost all or a substantial part of their deductibility for tax purposes have less value than like assets eligible for full deduction allowances. The unused tax basis is frequently a significant consideration in property transactions. Economically this is just as significant as obsolescence or wear and tear.

Other infirmities make the assumption of permanent deferral an illusion. Experience teaches that the Internal Revenue Code is subject to revision whenever the fiscal requirements or the substantive policy of the government changes. A number of bills were introduced in the Congress to revise the liberalized depreciation provisions of the Code. ${ }^{19}$ Adherents of the permanent saving philosophy are constantly hammering for repeal of the liberalized depreciation provisions, and have gone so far as to urge the "out-right elimination of the allowance for depreciation for tax purposes." 20

Adequate protection for the ratepayer is assured by the normalization principle even if the tax deferral were to become permanent. In that event, the interest-free fund of capital would continue permanently for the exclusive benefit of the ratepayers. But any assumption of permanence overlooks the vigilance of the Congress, which has been quick to react to any practices or decisions that tend to frustrate its legislative intent. To keep the Congress fully and currently informed there are the able technical staffs of both Houses and the Treasury.

Foreign countries that have pioneered in liberalized depreciation have reduced or suspended its force in order to curb inflationary pressures and discourage excessive capital expenditures. 21 At the beginning of its defense emergency, Great Britain suspended its partial allowance of $40 \%$ and did not restore it until a few years ago. Following the Korean War, Canada denied depreciation on capital investment for a period of four years other than in defense industries. Sweden, a pioneer in flexible depreciation, has substantially restricted the scope of optional rates.

Moreover, no enterprise is free from the risk of fluctuations in annual replacements or additions. The fat years and the lean years are reflected in the rate of facility expansion of many utilities. The possibility of far-reaching technological changes may not be ruled out.

Nor is there any universal pattern of consistency or acceleration in the

19 H.R. No. 127, H.R. No. 4806, H.R. No. 8120, 9544, 85th Cong., 1st Sess. (1957).

20 Tax Revision Compendium submitted to the Committee on Ways and Means in connection with the Panel Discussions on the same subject by Committee on Ways and Means, beginning November 15, 1959, vol. 2, p. 799. (1953).

21 Slitor, Liberalization of Depreciation, 46TH ANNUAL CONFERENCE ON TAXATION 466 
rate of capital expenditures. The airlines provide a graphic illustration in the purchase of jets within one year or two in replacement of almost entire fleets of piston-powered equipment. The gigantic expenditures for jet planes, training facilities, parts and maintenance equipment are not likely to be equalled for a great many years. Even in the electric power industry, the advent of automation, the expanding influence of electronic development, and the research in direct conversion of heat or chemical energy into electricity deny any assurance of constancy in plant growth.

It is precisely in the areas in which cash disbursements do not lend themselves to a measure of the expense or the appropriate period of allocation that accounting techniques must be invoked. They serve systematically to measure the expense, to match the expense against the revenue of the proper period, and to reflect the consequences in the financial condition of the company.

It is neither good business nor good accounting to ignore a future liability because there is a great probability that when the liability matures, and is paid, the cash for the payment will be provided by the incurring of another liability-and that this will continue ad infinitum.

The regulatory requirement of flow-through accounting must necessarily have an adverse impact upon the financial standing and credit of regulated utilities. The theory gets its label from the fact that the misnamed saving would flow right through to net income. No careful analyst would fail to take into account the consequent overstatement of current income and the uncertainties of the future. There can be no assurance that future commissions will be willing to impose upon future consumers the onus of income taxes attributable to present taxable income. Analytical reports of railroad operations consistently note the extent to which reported income has been inflated by the tax "savings." A similar concern has already appeared in studies of public utilities. The item is separately reported in the principal statistical reports of utility earnings. 22

The overhanging burden of unfunded deferred taxes imposes an additional risk which must sooner or later reflect itself in the cost of equity, and perhaps even debt, financing. New York has already recognized that such risk must increase the allowable rate of return but without separately identifying the allowance or requiring accounting therefor.

The normalization method simply records the reality of the tax deferral both in the income and in the balance sheet accounts. The warrant for such

22 A special report on Pacific Gas and Electric Company and Southern California Edison Company, recently issued by a Wall Street brokerage firm, recognizes that the inflation in earnings, attributable to the adoption of flow-through, has tended to retard the market appraisal of the shares of those companies. The analysis recognizes that normalization would enhance the cash flow and reduce the future financing requirements of the utility, while flow-through would render uncertain the maintenance of existing earning levels. H. Hentz \& Co., Special Research Bulletin, April 14, 1961. 
time-honored accrual accounting has been recognized by the Federal Power Commission and the numerous state commissions that have been willing to face up to more than the immediate effect upon the current year's tax payment. It conforms to the command of the courts that regulatory bodies allow as operating expenses "reserves that are necessary in good business judgment and operations." 23

A taxpayer can reduce tax payments early in an accelerated depreciation schedule only by in effect contracting for higher payments in the future. Sound accounting takes such interrelationship into account, permitting an orderly allocation of tax costs to the appropriate periods. Being realistic in concept, normalization assures stability. The withdrawal or revision of the interest-free loan arrangement by statutory change or otherwise could not upset the utility's financial accounts, credit or rates of charge.

Normalization assures equality of treatment to present and future customers. Each pays its fair share of depreciation and income tax, each benefits from the interest-free capital the Congress has provided. It avoids an unrealistic windfall to present customers and a reservation of unfair burdens for future customers. The direct benefits may readily be allocated by the commission. Normalization has the wholesome characteristic of honesty, reflecting the purposes of the Congress. There is a simplicity in permitting the normal income tax expense to remain undistributed while making the interest-free capital benefits readily available. No extraordinary risks or assumptions need be invoked fully to recognize those capital benefits in consumer rates. Rates of charge are not subject to violent fluctuation nor is confidence in the financial reports or credit standing of the utility impaired. The normalization and reserve principles strengthen the capital structure of the utility and enhance its financial stability, facilitating financing of new capital requirements at reasonable costs. This is a service to the investor and consumer alike and accords wholesomely with the public interest.

Shareholders are not free from risk in the normalization of income taxes. An increase in tax rates, directly or through an excess levy, could impose a burden beyond the available reserve. The extent to which such increased cost for accrued items could be recovered in rates is highly speculative. ${ }^{24}$ And it should be recalled that this risk to shareholders grows out of the utility's voluntary tax procedures from which all of the monetary benefits move to the consumer under the appropriate normalization policy. This may explain the adherence of some utilities, notably the A.T. \& T. subsidiaries, to straight-line methods of computing depreciation credit against taxable income. In any event, should tax rates be reduced, the accumulated reserve

23 Illinois Bell Tel. Co. v. Illinois Commerce Comm'n, 414 III. 275, 286, 111 N.E.2d 329,335 (1953).

${ }^{24}$ Cf. Re Union Elec. Co., 29 P.U.R.3d 177 (IIl. C.C. 1959). 
remains under the control of the Commission, which has the power to assure customers their full share of benefits from the accumulated reserve.

The heavy additional risks to investors inherent in the flow-through method serve to discourage an election to apply liberalized methods in jurisdictions imposing that accounting procedure. While some regulatory coercion has been used, 25 there is an authoritative recognition that the discretion under section 167 with respect to the depreciation methods to be applied in tax computation is lodged with the utility management. 26

The Board of Transport Commissioners for Canada authorized normalization by Bell Telephone Company of Canada, and the Governor in Council reversed, requiring flow-through. 27 Thereupon the utility returned to straightline depreciation for tax purposes and rates predicated thereon were approved. The Governor in Council sustained the regulatory commission, holding that the utility is free to follow either method permitted by the tax laws. 28

This understandable pattern of self-protection is a consequence of the over-reaching inherent in flow-through and denies the statutory advantages to both the utility and its customers.

The attack upon orderly accounting treatment has come from both flanks. With excessive zeal for the present consumers, flow-through is urged to give them a windfall. No less selfishly imprisoned is the thinking that the risk capital should get the full incentive which the Congress fashioned for investors in all enterprises alike. Rational accounting procedure and due regard for stability of rates requires rejection of both extreme positions. All income tax accumulations are derived from funds provided by the ratepayer be they for tax payments currently due (with the accumulations extending over a period of months) or for income taxes upon which the payment is deferred for a considerable number of years. As to the short term, accumulations are treated as available working capital upon which a rate of return has been denied.29 The longer term reserve should be treated in the same manner.

\section{Determination of Generally Accepted Accounting Principles}

The main body of opinion among business executives and their auditors accords with normalization and reserve principles. Initial attitudes in the

25 Re New England Tel. \& Tel. Co., 23 P.U.R.3d 510 (Me. P.U.C. 1958); Re New England Tel. \& Tel. Co., 21 P.U.R.3d 195 (N.H.P.U.C. 1957).

26 City of Pittsburgh v. Pennsylvania Pub. Util. Comm'n, 187 Pa. Super. 341, 144 A.2d 648, 658 (1958); $\operatorname{Re}$ California Water \& Tel. Co., California Comm'n decision No. 55359, p. 8 (1957); Re Tax Treatment of Accelerated Depreciation 33 P.U.R.3d 209 (P.U.C. Cal. 1960); Application of Diamond State Tel. Co., 48 Del. 317, 103 A.2d 304, 324 (1954), aff'd, 48 Del. 497, 107 A.2d 786 (1954); Application of Diamond State Tel. Co., 51 Del. 525149 A.2d 324 (1959).

2776 C.R.T.C. 1 (1958); Order in Council, P. C. 1958-602.

2878 C.R.T.C. 1 (1958); Order in Council, P.C. 1958-1625.

29 Alabama-Tennessee Natural Gas Co. v. F.P.C., 203 F.2d 494, 498 (3rd Cir., 1953); City of Alton v. Commerce Comm'n, 19 Iil. 2d 76, 165 N.E.2d 513 (1960). 
accounting profession, accepting the flow-through theory as permissible, have now given way under the impact of debate and experience. Nevertheless, auditors have accepted the flow-through theory for utilities operating in jurisdictions in which that approach to the problem has been adopted or approved by the regulatory body.

The prevailing accounting practice among business corporations is to use accelerated methods for books and taxes, to normlaize income taxes as an expense and to reserve the accruals. A study made by the Comptrollers Institute Research Foundation, Inc., disclosed that out of 994 companies responding to a questionnaire, 738 were taking accelerated depreciation for tax purposes. Of that number, only 52 companies were permitting net income to be increased by the flow-through method. The survey included 122 utilities of which 71 were taking accelerated depreciation; of these, all but 16 used normalization. 30

Initially, the official position of the accounting profession was a straddle. Accounting Research Bulletin No. 44, issued by the Committee on Accounting Procedure of the American Institute of Certified Public Accountants in October 1954, held that recognition may, but need not, be given to the deferred taxes associated with accelerated depreciation. ${ }^{31}$ No purpose would be served by detailing the nature and intensity of the cross-currents of opinions or variety of arenas in which debates ensued. It is sufficient to note that in July 1958, Accounting Research Bulletin No. 44 was revised and the new release expressly superseded the earlier one. The bulletin found that "where material amounts are involved, recognition of deferred income taxes in the general accounts is needed to obtain an equitable matching of costs and revenues and to avoid income distortion, even in those cases in which the payment of taxes is deferred for a relatively long period." To accomplish that objective, the bulletin required that recognition be given to deferred income taxes where "the declining balance method is adopted for income-tax purposes, but other appropriate methods are used for financial accounting purposes." 32

An interpretative letter dated April 15, 1959, from the Institute's Committee on Accounting Procedure, clarified the reference in revised Bulletin No. 44 to "a deferred tax account." 33 The Committee said:

The committee used the phrase in its ordinary connotation of an account to be shown in the balance sheet as a liability or a deferred credit. A provision in recogni-

30 Comptrollers Institute Research Foundation, Inc., Survey of Corporate PracTICE WITH REspect to ACCelerated Depreclation for TAX PuRPoses (1960).

31 Commttre on Accounting Procedure, American Institute of Certified Public

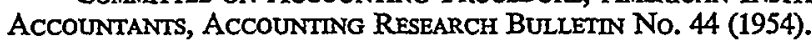

32 Committee on Accounting Procedure, American Institute of Certified Public AcCoUntaNTs, ACCOUNIING RESEARCh BULLETIN No. 44 (revised) (1958).

33 Commtrtee on Accounting Procedure, American Institute of Certified Public AccountanTs, letter to the members of the Institute, April 15, 1959. 
tion of the deferral of income taxes, being required for the proper determination of net income, should not at the same time result in a credit to earned surplus or to any other account included in the stockholders' equity section of the balance sheet. ${ }^{34}$

In the matter of depreciation, judicial reliance upon the prevailing opinion of public accountants and businessmen has been supported by no less a champion of the ratepayer than Mr. Justice Brandeis. ${ }^{35}$

\section{Treatment of DeferRed Federal Income TAXes BY THE REGULATORY COMMISSIONS}

A summary of regulatory decisions with respect to the treatment of accelerated depreciation and deferred federal taxes, in accounting and rate proceedings, has been provided in the Appendix. When the problem first arose, there was a tendency on the part of regulatory bodies to seize upon the flowthrough theory as a means of holding rates in line, or effecting reductions. The uncertain attitude of the accounting profession which made flow-through acceptable to auditors lent support to this approach. As the problem underwent increasingly critical examination, the more orderly normalization approach emerged and found broad acceptance. In some jurisdictions, the prevailing opinion has undergone change from one theory to the other. ${ }^{36}$

The better regulatory opinion is that the income tax expense should be normalized in the income accounts. This principle applies where a utility computes the depreciation expense on a straight-line basis, but employs an accelerated method to compute the tax deduction. The normalization accounting principle is now being applied by the Federal Power Commission, the Civil Aeronautics Board and regulatory commissions in twenty-five

34 Before that letter could be released, operating utilities of the American Electric Power Company instituted suit to enjoin the distribution of the letter until the matter could be examined by "the persons to whom the exposure draft of Accounting Bulletin 44 was submitted." The relief was denied. Appalachian Power Co. v. American Institute of Certified Public Accountants, 177 F. Supp. 345 (1959), aff'd, 268 F.2d 844 (2d Cir.), cert. denied, 361 U.S. 887 (1959). The action is indicative of the intensity with which investors' claims are pressed, matching that of flow-through advocates on the other extreme. The SEC declined to permit the same company to include accumulated deferred taxes as a restricted surplus account in the equity component of the capitalization for purpose of determining compliance with SEC holding company standards. See Appendix item 14.

The annual reports for three large electric utilities, all audited by the same accounting firm, reveal the divergence of practice that the accounting profession is willing to sanction. Consolidated Edison Company received an unqualified certificate for its accounts that consistently reflect the flow-through theory. The Detroit Edison Company accounts, using normalization, were similarly certifed without qualification by the same accounting firm. Long Island Lighting Company replaced normalization with flow-through in conformity with the policy adopted by the New York Public Service Commission. In 1959 the auditor's certificate approved the changed approach as "an acceptable alternative method." The 1960 certificate is completely unqualified.

35 United Rys. \& Elec. Co. v. West, 280 U.S. 234, 274 (1930) (dissenting opinion).

${ }^{36}$ E.g., Maine, Missouri, Ohio (see Appendix for citations). 
states. ${ }^{37}$ Save where inhibited by state regulation, the Securities and Exchange Commission has shown a preference for normalization accounting.

The flow-through theory is now approved, with varying limitations and modifications, by the Interstate Commerce Commission and regulatory commissions in eighteen states and the District of Columbia. ${ }^{38}$ Included in this number are New Mexico and Vermont, ${ }^{39}$ in which certain classes of utilities are permitted normalization, Ohio, where a shift in policy by the commission is awaiting judicial review, 40 and California, where the acceptance of flowthrough is already in official jeopardy. The I.C.C. system of accounts has long been at variance with both generally accepted accounting principles and the uniform system generally applied to utilities by the state commissions.

In the regulatory opinions sustaining normalization, the various arguments revolve around the central theme that "the charging of greater depreciation during the early life of property and the charging of less during the later life operates to create a deferral of income taxes."41 Coupled with this consideration is the oft-cited fact that the accumulation of a reserve for deferred federal taxes provides an interest-free fund of capital upon which ratepayers are not required to provide a return. Thus, the full direct benefit of the accelerated depreciation taken inures to the ratepayer and the indirect benefit of a stronger capital structure serves the interests of all parties. The Supreme Court of Illinois had occasion, in granting rehearing, to approve the normalization of taxes in the expense account upon the express condition that the resultant reserve for deferred taxes should be taken as a reduction in the rate base so that the capital represented thereby would require no return from the ratepayers. 42

The flow-through theory rests on the conviction that the only federal income taxes to which ratepayers should contribute are those actually accrued, as a matter of law, and paid for the current period. The fact that current operations will give rise to additional income taxes after the depreciation deduction under the accelerated method drops below that provided by the straight-line method is regarded as too remote and indefinite to require present taxpayers to provide the funds at this time. To this is added the

37 Alabama, Arkansas, Florida, Georgia, Hawaii, Illinois, Indiana, Kansas, Kentucky, Louisiana, Maryland, Massachusetts, Michigan, Minnesota, Mississippi, Nebraska, Nevada, New Mexico (telephone utilities only), Oklahoma, South Carolina, Tennessee, Vermont (water and telephone utilities only), Virginia, Wisconsin, and Wyoming. Citations appear in Appendix.

38 See notes 5-6 supra.

${ }^{39} \mathrm{Re}$ General Tel. Co., 14 P.U.R.3d 243 (N.M. Corp. Comm'n 1956); Re Accounting Treatment of Accelerated Depreciation (Vt. P.U.C., December 3, 1958).

${ }^{40} \mathrm{Re}$ Cincinnati Gas and Elec. Co. proceeding on appeal to the Ohio Supreme Court. ${ }^{41}$ Amere Gas Util. Co., 15 F.P.C. 760, 782 (1956).

42 City of Alton v. Commerce Comm'n, 19 Ill. 2d 76, 165 N.E.2d 513 (1960). 
argument that no one can predict what the future will hold in taxes, either in terms of rates or permissible methods of computation. The reserve accounting procedure, inherent in normalization, is rejected in favor of a supposedly realistic expectation that utilities will continue their large scale capital investment in the foreseeable future, putting off indefinitely any reduction in accelerated depreciation credits below the straight-line level. This is taken to spell a permanent tax deferral.

The most articulate advocacy of the flow-through theory appears in a recent dissenting opinion of Commissioner Connole of the Federal Power Commission. In In the Matter of United Fuel Gas Co.,43 he amplified his earlier decision in the Amere ${ }^{44}$ case, saying:

I reasoned that as long as the reserve would never be charged and as long as the current accruals for federal income tax purposes would never be less than the actual federal income tax liability due and payable in any tax year, a regulated utility ought not to be allowed an operating revenue deduction to meet this nonexistent liability.

Inherent in this reasoning is the concession that the tax is deferred and must be paid in future years. The argument gets down to the fact that no cash will be required in the future because the liability will be offset by equal or larger depreciation from future additions. This netting process, however refined, is wholly inconsistent with systematic accounting. The Connole rationale can be applied with equal validity to depreciation charges, pension fund appropriations and, indeed, even long-term funded indebtedness. In rejecting the offsetting theories advanced against deferred tax charges, Professor Maurice Moonitz of the University of California had this to say: "The fact that a going-concern always has debts which are never 'really' paid off, because any given debt, when satisfied, is replaced by a new debt, is no argument for eliminating the debts from the financial statements." 45

How closely the Connole reasoning follows that which deprecated depreciation accounting in the twenties is revealed by his further statement: "Experience tells us that the possibilities of retirements at cost exceeding replacements and expansions of facilities are non-existent in the utility industry generally." 46 If that be the test, why bother with depreciation accounting? Connole is sounding a dangerous call for a return to the discredited retirement theories of the pre-depression years. Indeed, the dissenting Commissioner found himself compelled to brush off as "irrelevant and non-recurring" the gigantic write-offs in plant accounts that came with the depression. The truth is that these plant adjustments, aggregating $\$ 1.9$ billion, 47 could

${ }^{43}$ CCH UTIL. L. REP., II 10022 (F.P.C. January 22, 1960).

4415 F.P.C. 760 (1956).

45 Moonitz, Income Taxes in Financial Statements, 32 Accounting Rev. 181 (1957).

46 Ibid.

47 F.P.C. 27tre ANN. REP. 45, 73 (1957). 
in large part have been avoided had depreciation reserves been systematically accumulated realistically to reflect the consumption of the property.

Nor is the issue clarified by a debate as to whether or not Congress intended "that these benefits be retained by regulated utilities." 48 No intention regarding this question is revealed; the legislative history is instructive only as to the nature of the incentive created by Congress. Similarly theoretical is the argument that such incentive for modernization and expansion is unnecessary in the case of utilities because they may look to the ratepayers to finance such construction. The fact is that the allowance of a reasonable rate of return does not guarantee that such return will be earned. In any event, the wisdom of extending the incentive to the utilities, or the lack of it (which is for the Congress), cannot change the nature of the incentive as a tax deferral.

The difficulty of anticipating the tax assessment of the future does not convert a current tax deferral into a tax saving. Neither the period of time nor the inability to anticipate future tax rates or deductions with precision excuse the need for a reserve to meet the deferred taxes when they mature in the future. Depreciation charges themselves, as well as pension provisions, span at least as great a period and, inevitably, the amounts of the charges must rest upon informed estimates. It would be folly to eliminate all provision for future payments simply because anticipatory exactitiude cannot be achieved. Transcending all argument on the permanency of the deferral is the stubborn fact that if Congress had intended a rate reduction for business enterprises, a cut in the tax rate would have been simple and direct.

The application of the normalization principle to tax deferrals arising from the five-year amortization, now codified in Section 168 of the Code, has been consistently upheld by the courts called upon to deal with the subject.49 No difference in principle is discernible between five-year amortization and accumulated depreciation for tax purposes. The period of time for the higher tax payments may be longer, but the principle is identical.

It is significant that utilities cover the whole spectrum of depreciation lives. Buses generally have a ten-year service life. Airplanes have service lives as low as five years. That cannot logically be distinguished from the five-year amortization process by which the payback begins in the same year.

Some tribunals have argued that the choice of the depreciation method lies with the utility and that it must accept as the tax deduction the computation yielded by its choice of depreciation methods. 50 As a consequence, a number of utilities in flow-through jurisdictions have returned to the straight-

48 City of Pittsburgh v. Pennsylvania Pub. Util. Comm'n, 182 Pa. Super. 551, 128 A.2d 372, 381 (1956).

49 City of Detroit v. FPC, 230 F.2d 810 (D.C. Cir. 1955), cert. denied sub nom. Panhandle Eastern Pipe Line Co. v. City of Detroit, 352 U.S. 829 (1956); Public Serv. Co. v. New Hampshire, 102 N.H. 150, 153 A.2d 801 (1959); Hackensack Water Co. v. Board of Util. Comm'rs, 57 N.J. Super. 180, 154 A.2d 212 (1959).

50 See Re Piedmont Natural Gas Co., 34 P.U.R.3d 1 (N.C. 1960). 
line method. This eliminates the tax deferral permitted by the Congress, denying its benefits to both ratepayers and shareholders. Some flow-through jurisdictions have held that it is the duty of the utility to keep its cost at the lowest possible level; hence, if accelerated depreciation yields a lower tax, that method must be utilized and the reduction in current tax costs passed on to the taxpayer. 51

\section{Disposition OF THE RESERVE FOR DEFERRED TAXES}

As might be expected, neither the utility industry nor the regulatory bodies have been of one mind in allocating between the investor and the consumer the benefit of the interest-free capital yielded by the use of accelerated depreciation methods in taxation. In theory, the disposition of that interest-free fund of capital should present no problem. The cost of service philosophy of regulation contemplates that rates shall be sufficient to reimburse the utility for its actual cost of rendering the service, including the cost of debt and equity capital. The latter item appears as an allowed rate of return and is designed primarily to reflect the actual cost of capital.51a Since the capital represented by the reserve for deferred federal income taxes is available to the utility without charge, no recovery is required for that component in estimating the cost of capital. The full utilization of the capital provided by the reserve thus inures to the ratepayer without expense. This is warranted both by the principle that the utility should operate on the most economical basis consistent with good service and sound finance and the fact that the funds for normalizing the tax expense and accumulating the reserve are derived from consumers' rates.

Most states in which normalization obtains require that the ratepayers be given the free use of plant facilities financed by the interest refund of capital.52 Indeed, that principle has been imposed by the Illinois Supreme Court as a condition to the allowance of normalization in expense. $53 \mathrm{~A}$ simple technique for the protection of the consumer is to deduct from the rate base upon which a reserve is allowed the full amount of reserve for income taxes. 54

51 See $R e$ New England Tel. \& Tel. Co., 23 P.U.R. 510 (Me. 1958); Re Bangor HydroElec. Co., 26 P.U.R.3d 489 (1958).

513 Bonbright, Principles of Public Utility Rates 241 (1961).

52 See, e.g., City of Alton v. Commerce Comm'n, 19 Ill. 2d 76, 165 N.E.2d 513 (1960); Re Empire Dist. Elec. Co., 23 P.U.R.3d 45 (Kan. 1958); Re Honolulu Rapid Transit Co., 28 P.U.R.3d 1 (1959); Re Georgia Power Co., 10 P.U.R.3d 295 (1955), reaff'd, Dtk. 838 U (October 24, 1960).

53 City of Alton v. Commerce Comm'n, 19 Ill. 2d 76, 165 N.E.2d 513 (1960). Where the rate base must be determined on the basis of current fair value, an appropriate application of the principle would require that the original cost of the rate base be adjusted to reflect the year-to-year contributions to the reserve for deferred federal taxes. The estimates of current value, trended from the original costs, would then fairly reflect the free use by the ratepayers of facilities provided by the reserve for deferred federal taxes.

54 This method was approved by the Illinois Commerce Commission in $R e$ Commonwealth Edison Co., 24 P.U.R.3d 209 (III. C.C. 1958). 
Ratepayers are thus given free use of plant facilities financed by the interestfree fund of capital. Equally sound in theory but less demonstrable in practice is an appropriate reduction in the estimated cost of capital and hence in the allowable rate of return. ${ }^{55}$ Because the rate of return is necessarily an estimated or judgment figure, the adjustment of this rate-making factor gives less assurance that the ratepayers will receive the full advantage of the interestfree capital. Instead of a provision for deferred federal income taxes, Wisconsin has authorized an increase in the depreciation allowance in the same amount. This, in turn, is added to the reserve for depreciation deducted from the rate base. 56

Recently, the Securities and Exchange Commission required a holding company to exclude from capitalization the accumulated tax reserve. 57 Rejected was the utility's effort to treat the tax credit as a restricted part of surplus so as to enhance the common equity available to meet the SEC capitalization standards. A settlement was approved permitting an involved description of the reserve but excluding it from capital in the computation of acceptable ratios of funded debt, preferred stock and common equity.

An investigation into the subject of deferred federal income taxes resulting from accelerated depreciation by the California Commission evoked a proposal by a number of utilities that normalization be allowed and that the rate of return on the accumulated reserve for federal income taxes be limited to some $3 \%$. This would have had the effect of dividing the benefits between investors and consumers. The Commission rejected this approach, adopting at the outset the flow-through method. 58 More recently, with a change in Commission membership, a supplemental order was issued authorizing companies which have not had a general rate case since the original order was made by the Commission to normalize their taxes, accumulating the credits in the depreciation reserve. 59 Carried to its logical conclusion, this would lead to the adoption of the Wisconsin principle which accepts normalization and, through the use of the depreciation reserve, would pass on the full benefit of the interest-free capital to the ratepayers. The division of opinion revealed by the California Commission suggests that the last word has not yet been written on the status of deferred federal taxes under California regulation. 60

s5 See Re Empire Dist. Elec. Co, 23 P.U.R.3d 45, 53 (Kan. Corp. Com. 1958); Re The Peoples Gas Light \& Coke Co., 27 P.U.R.3d 209, 227,232 (Ill. C.C. 1959).

56 Re Wisconsin Fuel \& Light Co., 12 P.U.R.3d 254 (1956).

57 See item 14 of Appendix.

58 Re Tax Treatment of Accelerated Depreciation, 33 P.U.R.3d 209 (1960).

59 Supplemental Accounting Order, Decision No. 61711, Case No. 6148 (March 21, 1961).

60 Particularly difficult to understand is the comment that "There can be no doubt that the true flow-through results only when both income tax expense and rates are determined on the basis of the use of liberalized depreciation." The dissenting opinion, filed by two of the Commissioners who had approved the original order, holds that the latest action 
The participation of investors in the interest-free capital, unsuccessfully urged in the California investigation, has received significant sanction from the Federal Power Commission in the recent Northern Natural Gas Co. decision. ${ }^{61}$ It was there held that the company should be allowed a return of $1.5 \%$ upon the facilities represented by the reserve for deferred federal taxes. This was described as a "sufficient incentive to a regulated company to induce it to take advantage of Section 167."62 The Commission felt that any appreciably lower allowance would probably cause the company to return to straight-line depreciation with corresponding loss of benefits to the ratepayer. This reasoning overlooks the obligation of the utility to conduct its affairs, consistent with sound business and financial practice, to produce the lowest reasonable cost to the consumer. It is not for the utility to say that it will decline to follow a reasonable course calculated to produce lower costs for the ratepayer unless it receives some special compensation for so doing. The right to exercise a utility franchise carries with it the responsibility of reasonable protection of the rights of the ratepayer. If the flow-through method is sound, regulatory agencies should properly enforce its use. But if normalization with its accrual of a reserve for deferred federal taxes reflects sound accounting practice, that procedure should be required. And in each instance the requirement should be based upon sound regulatory practice rather than special compensation to the utility.

\section{Judictal Review}

The role of the courts in determining the treatment to be accorded to accelerated depreciation benefits enjoyed by utilities has been necessarily circumscribed in part by the expertise attaching to commission decisions. Where there are competing theories respecting the accounting treatment of depreciation and tax accruals attributable to current taxable income, any reasonable choice by the commission is free from judicial review. 63 The decisions sustaining flow-through have consistently relied upon this principle but generally go further and give sanction to the flow-through theory itself. 64

tends to reverse the present trend in the use of liberalized depreciation and hence "will inevitably lead to further rate increases." The fact is that normalization does not change a utility's income level, and the flow-through theory is simply a device for reducing the apparent level of the income and hence rates of charge.

61 Opinion No. 342 (March 7, 1961).

62 Ibid.

${ }^{63}$ Railroad Comm'n v. McDonald, 90 S.W.2d 581 (Tex. Civ. App. 1936); City of Cincinnati v. Public Util. Comm'n, 151 Ohio St. 353, 86 N.E.2d 10 (1949); New York v. United States, 98 F. Supp. 855, aff'd, 342 U.S. 882 (1951), rehearing denied, 342 U.S. 911 (1952).

64 Boone County Rural Elec. Membership Corp. v. Public Serv. Comm'n, 159 N.E.2d 121 (Ind. 1959); Central Maine Power Co. v. Public Util. Comm'n, 153 Me. 228, 136 A.2d 726 (1957); City of Pittsburgh v. Pennsylvania Pub. Util. Comm'n, 182 Pa. Super. 551, 128 A.2d 372 (1956). 
The Maine and Pennsylvania opinions are so defensive of the flow-through theory as to deny, in essence, any future freedom of choice to the regulatory agencies. The New Jersey courts affirmed entirely in deference to the reasonable determination of the commission, leaving the way open to a future change.

The Ohio courts now confront an interesting situation with respect to the Cincinnati Gas \& Electric Company. The original order of the Public Utilities Commission tentatively authorized the company to normalize taxes arising from the use of Section 167 of the Code but noted that in doing so it "neither accepted the characterization of the reduction in tax liability as a 'deferral' nor attempted to establish a policy in the matter." To resolve that uncertainty, the utility petitioned for rehearing. The Commission employed as an expert witness a determined advocate of flow-through and then adopted his concept that "the federal income tax is not levied on items of property but instead on income and that income taxes are calculated on income for an entire company as a whole." 65

The Supreme Court of Illinois initially reversed a normalization order of the Commission. 66 Upon rehearing the Supreme Court held that normalized taxes may be allowed as an expense upon condition that the accumulated reserve be deducted from the rate base so as to guarantee the ratepayers the free use of the capital accumulated out of their rates.67 On the specific ground that the use of the declining balance method of depreciation "works a tax deferral rather than a tax saving," the Court of Appeals for the Fifth Circuit sustained a normalization order of the Federal Power Commission and the Supreme Court has denied certiorari.68 The refusal of review is regarded as particularly significant because the court of appeals opinion squarely approved normalization on its merits, without reference to the discretion or expertise of the commission.

The support which the flow-through advocates originally found in the reported decisions has been somewhat dulled by the Illinois and Fifth Circuit opinions. These suggest a more thoughtful and balanced consideration of the problem by the courts that are yet to examine it.

65 Electric Light \& Power, vol. 39, No. 1, p. 24, January 1, 1961.

${ }^{66}$ City of Alton v. Commerce Comm'n, 19 Ill. 2d 76, 165 N.E.2d 513 (1960).

67 Ibid.

68 El Paso Natural Gas Co. v. Federal Power Comm'n, 281 F.2d 567, 573 (5th Cir. 1960), cert. denied, 366 U.S. 912 (1961). 


\section{APPENDIX}

Recent Rate and Accounting Decisions in Cases where Accelerated DePRECIATION WAS TAKen FOR TAX PURPOSES BUT NOT FOR BOOK PURPOSES

(THROUGH 1960)

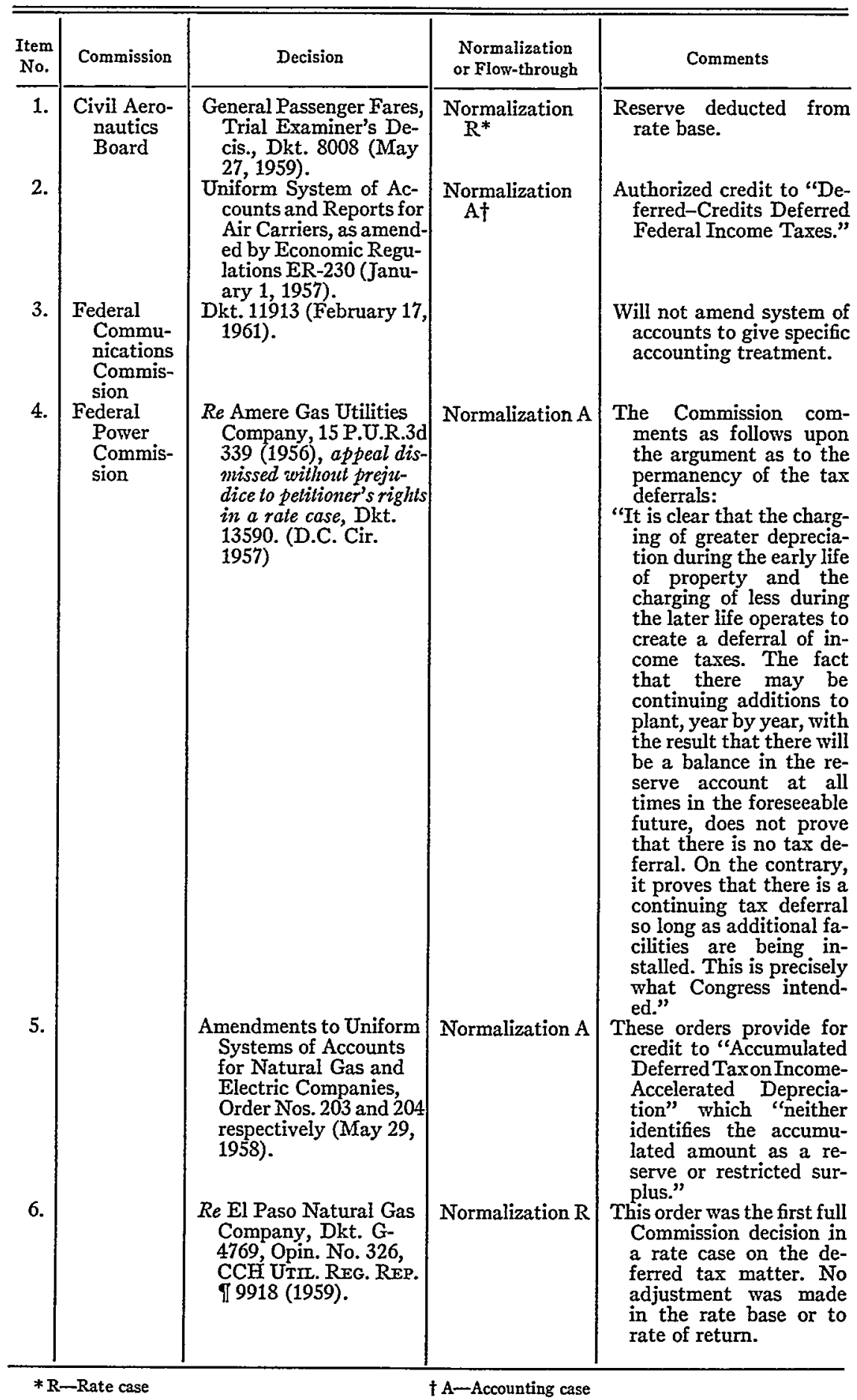


APPENDIX-Continued

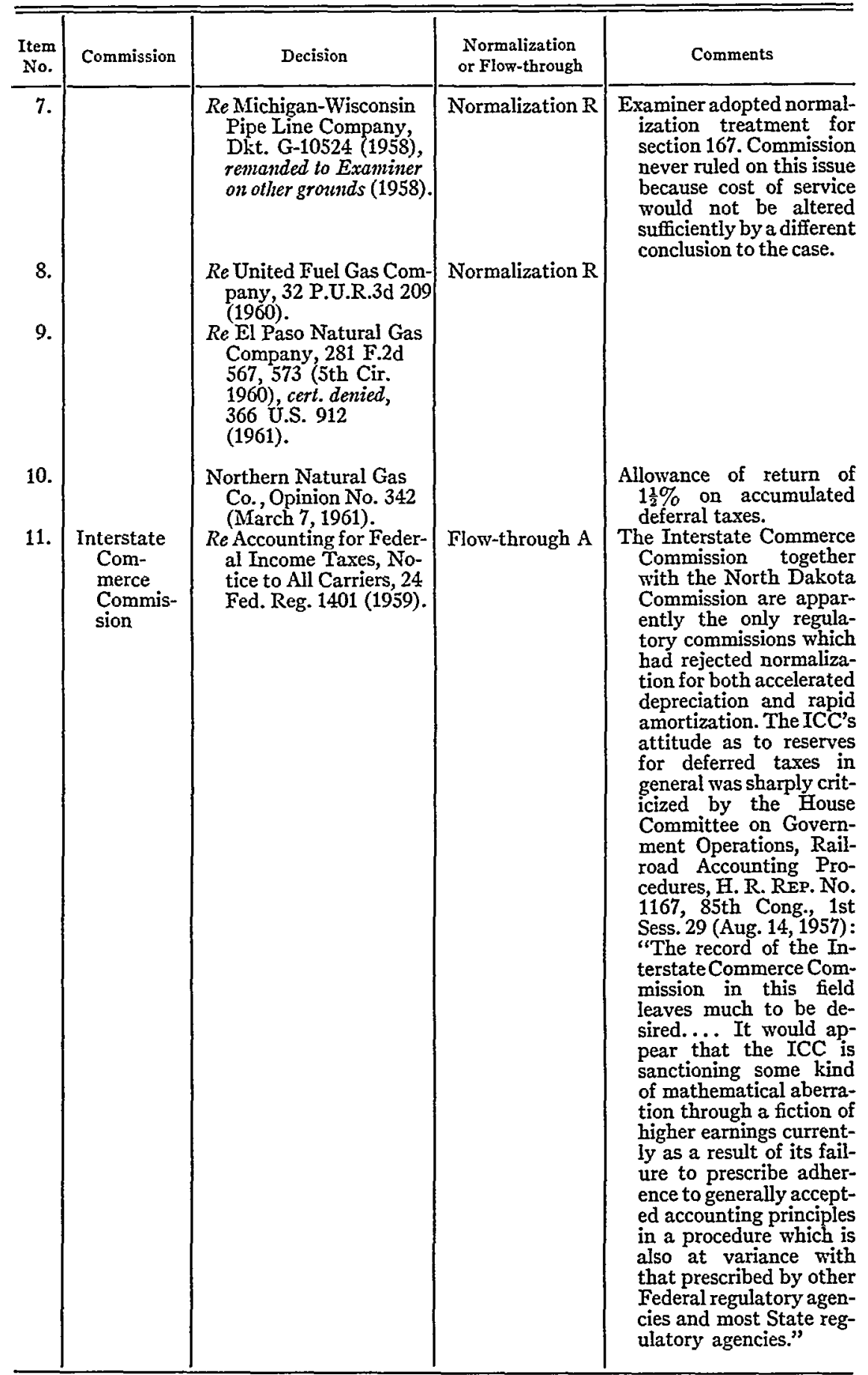




\begin{tabular}{|c|c|c|c|c|}
\hline $\begin{array}{l}\text { Item } \\
\text { No. }\end{array}$ & Commission & Decision & $\begin{array}{l}\text { Normalization } \\
\text { or Flow-through }\end{array}$ & Comments \\
\hline 12. & $\begin{array}{l}\text { Securities } \\
\text { and Ex- } \\
\text { change } \\
\text { Commis- } \\
\text { sion }\end{array}$ & $\begin{array}{l}\text { Notice of Intention to } \\
\text { Announce Interpreta- } \\
\text { tion of Administrative } \\
\text { Policy, CCH } \\
\text { FED. SEC. L. REP. } \\
\text { T 76633(1959). }\end{array}$ & $\begin{array}{r}\text { Normalization } \\
\text { (Pending) A }\end{array}$ & $\begin{array}{l}\text { This case deals primarily } \\
\text { with the accounting } \\
\text { presentation of the cred- } \\
\text { it arising from deferred } \\
\text { taxes. }\end{array}$ \\
\hline 13. & & $\begin{array}{l}\text { Statement of Policy re } \\
\text { Balance Sheet Treat- } \\
\text { ment of Deferred } \\
\text { Taxes, ASR 85 } \\
\text { (February 29, } \\
\text { 1960). }\end{array}$ & Normalization A & $\begin{array}{l}\text { This case deals primarily } \\
\text { with the accounting } \\
\text { presentation of the cred- } \\
\text { it arising from deferred } \\
\text { taxes. }\end{array}$ \\
\hline 14. & & $\begin{array}{l}\text { American Electric Power } \\
\text { Co. (Kentucky Power } \\
\text { Co.) } \\
\text { Holding Company Act } \\
\text { Release 35-14353 (Jan- } \\
\text { uary 26, 1961). }\end{array}$ & & $\begin{array}{l}\text { Deferred taxes excluded } \\
\text { from common stock } \\
\text { equity. }\end{array}$ \\
\hline 15. & Alabama & $\begin{array}{l}\text { Re Alabama Gas Corpo- } \\
\text { ration, Non-Dkt. 1704 } \\
\text { (January } 27,1956) .\end{array}$ & Normalization A & Deferred Tax Reserve. \\
\hline 16. & Arizona & $\begin{array}{l}\text { Re Arizona Public Serv- } \\
\text { ice Company, Dkt. } \\
\text { U-1345 (January 26, } \\
\text { 1959). }\end{array}$ & $\begin{array}{l}\text { Flow-through } \\
\text { A \& R }\end{array}$ & $\begin{array}{l}\text { Commission indicated that } \\
\text { flow-through treatment } \\
\text { would not necessarily be } \\
\text { applied to all other } \\
\text { utilities under its juris- } \\
\text { diction. Each case would } \\
\text { be considered in light of } \\
\text { the applicable facts. }\end{array}$ \\
\hline 17. & Arkansas & $\begin{array}{c}R e \text { General Telephone } \\
\text { Company of the South- } \\
\text { west, Dkt. U-1101 } \\
\text { (September } 17,1956) .\end{array}$ & Normalization A & Deferred Tax Reserve. \\
\hline 18. & California & $\begin{array}{l}R e \text { Investigation by Cali- } \\
\text { fornia Commission } \\
\text { concerning proper } \\
\text { treatment for rate- } \\
\text { making purposes to be } \\
\text { accorded accelerated } \\
\text { depreciation and ac- } \\
\text { celerated amortization, } \\
\text { 33 P.U.R.3d } 209 \\
(1960) \text {. }\end{array}$ & Flow-through $R$ & $\begin{array}{l}\text { With respect to accelerat- } \\
\text { ed depreciation the ma- } \\
\text { jority decision of the } \\
\text { Commission stated that } \\
\text { for the purposes of rate- } \\
\text { fixing, the Commission } \\
\text { will not allow as a } \\
\text { charge to operating ex- } \\
\text { pense for income taxes } \\
\text { any amount in excess of } \\
\text { the amount of income } \\
\text { taxes lawfully assessed } \\
\text { by the taxing authority } \\
\text { and paid by the utility. } \\
\text { Two Commissioners dis- } \\
\text { sented from the order. }\end{array}$ \\
\hline 19. & & $\begin{array}{l}\text { Supplemental accounting } \\
\text { order, Decision No. } \\
61,711 \text {, Case No. } 6148 \\
\text { (March 21, 1961). }\end{array}$ & Normalization A & $\begin{array}{l}\text { For accounting purposes } \\
\text { only, utilities which } \\
\text { adopted an accelerated } \\
\text { depreciation method for } \\
\text { the computation of fed- } \\
\text { eral income taxes subse- } \\
\text { quent to their last rate } \\
\text { proceeding before the } \\
\text { Commission, may con- } \\
\text { tinue to use normaliza- } \\
\text { tion. }\end{array}$ \\
\hline 20. & Colorado & $\begin{array}{l}\text { Re Public Service Co. of } \\
\text { Colorado, 18 P.U.R.3d } \\
1 \text { (1957). }\end{array}$ & Normalization A & $\begin{array}{l}\text { Restricted Surplus Ac- } \\
\text { counting. }\end{array}$ \\
\hline
\end{tabular}


APPENDIX-Continued

\begin{tabular}{|c|c|c|c|c|}
\hline $\begin{array}{l}\text { Item } \\
\text { No. }\end{array}$ & Commission & Decision & $\begin{array}{l}\text { Normalization } \\
\text { or Flow-through }\end{array}$ & Comments \\
\hline 21. & & $\begin{array}{l}R e \text { Public Service Co. of } \\
\text { Colorado, 34 P.U.R.3d } \\
186(1960) .\end{array}$ & Flow-through $\mathbf{R}$ & $\begin{array}{l}\text { To compensate for attri- } \\
\text { tion and erosion factors, } \\
\text { the Commission in this } \\
\text { case added back to the } \\
\text { rate base sums previous- } \\
\text { ly deducted for accu- } \\
\text { mulated deferred taxes } \\
\text { applicable to acceler- } \\
\text { ated depreciation and } \\
\text { amortization. }\end{array}$ \\
\hline 22. & Connecticut & $\begin{array}{l}\text { Re Housatonic Public } \\
\text { Service Company, } 22 \\
\text { P.U.R.3d } 1 \text { (1958). }\end{array}$ & $\begin{array}{l}\text { Actual straight- } \\
\text { line taxes } R\end{array}$ & $\begin{array}{l}\text { Company changed from } \\
\text { accelerated to straight- } \\
\text { line depreciation and } \\
\text { stipulated that if it re- } \\
\text { verted to accelerated de- } \\
\text { preciation it would re- } \\
\text { fund tax savings to cus- } \\
\text { tomers pro rata. }\end{array}$ \\
\hline 23. & $\begin{array}{l}\text { District of } \\
\text { Columbia }\end{array}$ & $\begin{array}{l}R e \text { Potomac Electric } \\
\text { Power Company, 28 } \\
\text { P.U.R.3d } 206 \text { (1959). }\end{array}$ & Flow-through $\mathrm{R}$ & $\begin{array}{l}\text { Company requested flow- } \\
\text { through treatment. }\end{array}$ \\
\hline 24. & Florida & $\begin{array}{l}\text { Re Gulf Power Company, } \\
\text { Tampa Electric, 10 } \\
\text { P.U.R.3d } 273 \\
\text { (1955), applicability } \\
\text { clarified, Order No. } \\
2422 \text { (December 12, } \\
\text { 1956). }\end{array}$ & Normalization A & $\begin{array}{l}\text { Restricted Surplus Ac- } \\
\text { counting; applicable to } \\
\text { all public utilities except } \\
\text { railroads and motor car- } \\
\text { riers. }\end{array}$ \\
\hline 25. & & $\begin{array}{l}\text { Southeastern Telephone } \\
\text { Co.,30 P.U.R.3d } 492 \\
\text { (1959). }\end{array}$ & Normalization $\mathrm{R}$ & $\begin{array}{l}\text { Reserve deducted from } \\
\text { rate base. }\end{array}$ \\
\hline 26. & Georgia & $\begin{array}{l}\text { Re Georgia Power Com- } \\
\text { pany, 10 P.U.R.3d } \\
259(1955), \text { reaffirmed, } \\
\text { Dkt. 838U. (October } \\
24,1960) .\end{array}$ & $\begin{array}{l}\text { Normalization } \\
\text { A \& R }\end{array}$ & $\begin{array}{l}\text { Deferred Tax Reserve de- } \\
\text { ducted from rate base } \\
\text { for rate purposes. }\end{array}$ \\
\hline 27. & & $\begin{array}{l}\text { General Telephone Com- } \\
\text { pany of the Southeast, } \\
28 \text { P.U.R.3d } 452 \\
\text { (1959). }\end{array}$ & Normalization $\mathrm{R}$ & $\begin{array}{l}\text { Reserve deducted from } \\
\text { rate base. }\end{array}$ \\
\hline 28. & Hawaii & $\begin{array}{l}R e \text { Honolulu Rapid } \\
\text { Transit Company, } 28 \\
\text { P.U.R.3d } 1 \text { (1959). }\end{array}$ & Normalization $\mathrm{R}$ & $\begin{array}{l}\text { Reserve deducted from } \\
\text { rate base. }\end{array}$ \\
\hline 29. & Idaho & $\begin{array}{l}\text { Re Washington Water } \\
\text { Power Co., 33 P.U.R. } \\
\text { 3d } 88 \text { (1960). }\end{array}$ & Flow-through $R$ & $\begin{array}{l}\text { It would appear from } \\
\text { wording of Commission } \\
\text { order that the company } \\
\text { did not claim deferred } \\
\text { taxes as an operating ex- } \\
\text { pense in its presentation } \\
\text { to the Commission. }\end{array}$ \\
\hline 30. & Illinois & $\begin{array}{l}\text { Re General Telephone } \\
\text { Company of Illinois, } \\
\text { Dkt. 2885 (December } \\
\text { 29, 1955). }\end{array}$ & Normalization A & Deferred Tax Reserve. \\
\hline 31. & & $\begin{array}{l}\text { Re Peoples Gas Light } \\
\text { and Coke Company, } \\
\text { Dkt. 44293 (May 23, } \\
\text { 1958), aff'd on rehear- } \\
\text { ing, 27 Pि.U.R.3d } 209 \\
\text { (1959). }\end{array}$ & Normalization $\mathrm{R}$ & $\begin{array}{l}\text { Intervenor's request to de- } \\
\text { duct reserve from the } \\
\text { rate base denied but in- } \\
\text { terest-free funds were } \\
\text { considered in determi- } \\
\text { nation of rate of return. }\end{array}$ \\
\hline 32. & & $\begin{array}{l}\operatorname{Re} \text { Commonwealth Edi- } \\
\text { son Company, 24 } \\
\text { P.U.R.3d } 209 \text { (1958). }\end{array}$ & Normalization $\mathrm{R}$ & $\begin{array}{l}\text { Reserve deducted from } \\
\text { rate base. }\end{array}$ \\
\hline
\end{tabular}


APPENDIX - Contimued

\begin{tabular}{|c|c|c|c|c|}
\hline $\begin{array}{l}\text { Item } \\
\text { No. }\end{array}$ & Commission & Decision & $\begin{array}{l}\text { Normalization } \\
\text { or Flow-through }\end{array}$ & Comments \\
\hline 33. & " & $\begin{array}{l}\text { Re Union Electric Com- } \\
\text { pany, 29 P.U.R.3d 177 } \\
(1959) .\end{array}$ & Normalization $\mathrm{R}$ & $\begin{array}{l}\text { The Commission allowed } \\
\text { normalized taxes as an } \\
\text { operating expense even } \\
\text { though Union, in line } \\
\text { with the Missouri Com- } \\
\text { mission's policy, sought } \\
\text { only actual taxes. In- } \\
\text { terest-free funds were } \\
\text { considered in determin- } \\
\text { ing rate of return. }\end{array}$ \\
\hline 34. & & $\begin{array}{l}\text { Re Alton Water Com- } \\
\text { pany, 22 P.U.R.3d 358, } \\
\text { rev'd, 26 P.U.R.3d 187, } \\
\text { af'd and modified, } \\
33 \text { P.U.R.3d 76, 19 } \\
\text { Ill.2d 76, 165 N.E.2d } \\
513(1960) .\end{array}$ & Normalization $\mathbf{R}$ & $\begin{array}{l}\text { Court stated that at the } \\
\text { time it thought it per- } \\
\text { missible for the Com- } \\
\text { mission to safeguard the } \\
\text { financial integrity of } \\
\text { utilities by normalizing } \\
\text { income taxes; the court } \\
\text { opinion said that the ac- } \\
\text { cumulated deferral tax } \\
\text { reserve should be de- } \\
\text { ducted from the rate } \\
\text { base. }\end{array}$ \\
\hline 35. & Indiana & $\begin{array}{l}R e \text { Public Service Com- } \\
\text { pany of Indiana, 12 } \\
\text { P.U.R.3d } 509 \text { (1956), } \\
\text { aff'd, Boone County } \\
\text { Rural Electric Corp. v. } \\
\text { Public Service Comm'n } \\
\text { 159 N.E.2d } 121 \text { (Ind. } \\
\text { 1959). }\end{array}$ & Normalization $\mathrm{R}$ & $\begin{array}{l}\text { This is one of the three } \\
\text { cases in which questions } \\
\text { as to the appropriate } \\
\text { rate treatment of } \\
\text { accelerated deprecia- } \\
\text { tion reached a highest } \\
\text { state court, the others } \\
\text { being Maine and Illi- } \\
\text { nois. The Commission } \\
\text { gave consideration to } \\
\text { the effect of interest-free } \\
\text { funds on capital costs }\end{array}$ \\
\hline 36. & & $\begin{array}{l}\text { Re Accounting Proce- } \\
\text { dure, 30 P.U.R.3d } 470 \\
\text { (1959). }\end{array}$ & Normalization A & $\begin{array}{l}\text { Authorized either reserve } \\
\text { for deferred Federal in- } \\
\text { come taxes or restricted } \\
\text { surplus treatment. }\end{array}$ \\
\hline 37. & & $\begin{array}{l}\text { Re Public Service Com- } \\
\text { pany of Indiana (Com- } \\
\text { mission Order of Janu- } \\
\text { ary 13, 1961). }\end{array}$ & Normalization $\mathrm{R}$ & $\begin{array}{l}\text { Deferred income tax ac- } \\
\text { count considered in rate } \\
\text { of return finding. }\end{array}$ \\
\hline 38. & Kansas & $\begin{array}{c}\text { Re Empire District Elec- } \\
\text { tric Company, 23 } \\
\text { P.U.R.3d } 45 \text { (1958). }\end{array}$ & Normalization $\mathrm{R}$ & $\begin{array}{l}\text { Reserve was treated as in- } \\
\text { terest-free capital in de- } \\
\text { termination of rate of re- } \\
\text { turn. The Missouri Com- } \\
\text { mission, which sat jointly } \\
\text { with theKansasCommis- } \\
\text { sion in this case, rejected } \\
\text { normalization in favor } \\
\text { of actual taxes in fxing } \\
\text { the Company's Mis- } \\
\text { souri rates. }\end{array}$ \\
\hline 39. & Kentucky & $\begin{array}{l}R e \text { Western Kentucky } \\
\text { Gas Company, 21 } \\
\text { P.U.R.3d 394 (1957). }\end{array}$ & Normalization $\mathrm{R}$ & $\begin{array}{l}\text { Reserve deducted from } \\
\text { rate base. }\end{array}$ \\
\hline 40. & & $\begin{array}{l}R e \text { Kentucky Utilities } \\
\text { Company, 22 P.U.R.3d } \\
113 \text { (1958). }\end{array}$ & Normalization $\mathrm{R}$ & $\begin{array}{l}\text { Reserve deducted from } \\
\text { rate base. }\end{array}$ \\
\hline 41. & & $\begin{array}{l}R e \text { General Telephone } \\
\text { Company of Kentucky, } \\
\text { Case No. 3499 (De- } \\
\text { cember 15, 1958). }\end{array}$ & Normalization $\mathrm{R}$ & $\begin{array}{l}\text { Reserve deducted from } \\
\text { rate base. }\end{array}$ \\
\hline
\end{tabular}


APPENDIX-Continued

\begin{tabular}{|c|c|c|c|c|}
\hline $\begin{array}{l}\text { Item } \\
\text { No. }\end{array}$ & Commission & Decision & $\begin{array}{l}\text { Normalization } \\
\text { or Flow-through }\end{array}$ & Comments \\
\hline 42. & Louisiana & $\begin{array}{l}\text { General Notice (February } \\
25,1955 \text { ). }\end{array}$ & $\begin{array}{l}\text { Normalization } \\
\text { A \& R }\end{array}$ & $\begin{array}{l}\text { Deferred Tax Reserve. } \\
\text { Notice states that pro- } \\
\text { cedure provided in Gen- } \\
\text { eral Order No. } 6172 \text { as } \\
\text { to rapid amortization, } \\
\text { deferred tax accounting, } \\
\text { should be applied as } \\
\text { to accelerated deprecia- } \\
\text { tion. Procedure con- } \\
\text { frmed in letter to } \\
\text { NARUC, dated June } \\
13,1955 \text {. }\end{array}$ \\
\hline 43. & Maine & $\begin{array}{l}\text { Re Maine Public Service } \\
\text { Company, 12 P.U.R.3d } \\
349(1956) .\end{array}$ & Normalization A & $\begin{array}{l}\text { Deferred Tax Reserve, } \\
\text { subsequently rescinded. }\end{array}$ \\
\hline 44. & & $\begin{array}{l}\text { Central Maine Power } \\
\text { Co., 17 P.U.R.3d } \\
452 \text { (1957), aff'd, Cen- } \\
\text { tral Maine Power Com- } \\
\text { pany v. P.U.C., 21 } \\
\text { P.U.R.3d 321,153 Me. } \\
\text { 228,136 A.2d } 726 \\
\text { (1957). }\end{array}$ & Flow-through $\mathrm{R}$ & $\begin{array}{l}\text { This was the first case in } \\
\text { which a state supreme } \\
\text { court ruled on the rate } \\
\text { treatment of accelerated } \\
\text { depreciation. The court } \\
\text { indicated that this is a } \\
\text { matter for determina- } \\
\text { tion by the Commission } \\
\text { and approved the Com- } \\
\text { mission's ruling as a } \\
\text { matter of law. }\end{array}$ \\
\hline 45. & & $\begin{array}{l}\text { New England Tel. \& Tel. } \\
\text { Co., 23 P.U.R.3d 510 } \\
\text { (1958). }\end{array}$ & $\begin{array}{l}\text { Actual straight- } \\
\text { line taxes } R\end{array}$ & $\begin{array}{l}\text { Company had not adopted } \\
\text { accelerated depreciation. } \\
\text { Commission stated, } \\
\text { however, that if it is } \\
\text { fairly able to make sav- } \\
\text { ings in expenses it would } \\
\text { have the responsibility } \\
\text { for doing so. }\end{array}$ \\
\hline 46. & & $\begin{array}{l}\text { Bangor Hydro-Electric } \\
\text { Co., 26 P.U.R.3d } 489 \\
\text { (1958). }\end{array}$ & $\begin{array}{l}\text { Compulsory } \\
\text { flow-through } \\
R\end{array}$ & $\begin{array}{l}\text { The Commission, in set- } \\
\text { ting rates as though ac- } \\
\text { celerated depreciation } \\
\text { had been claimed by the } \\
\text { company, states that } \\
\text { "the failure of the Com- } \\
\text { pany to use accelerated } \\
\text { depreciation in the test } \\
\text { year in computing its in- } \\
\text { come tax expense con- } \\
\text { stitutes an abuse of dis- } \\
\text { cretion which would } \\
\text { place an unfair burden } \\
\text { on its customers." }\end{array}$ \\
\hline 47. & Maryland & $\begin{array}{l}\text { Re Cumberland and Al- } \\
\text { legheny Gas Company, } \\
\text { Case No. 5545, Order } \\
\text { No. } 53384 \text { (April 24, } \\
\text { 1958). }\end{array}$ & Normalization $\mathrm{R}$ & $\begin{array}{l}\text { Reserve deducted from } \\
\text { rate base. }\end{array}$ \\
\hline 48. & $\begin{array}{l}\text { Massachu- } \\
\text { setts }\end{array}$ & $\begin{array}{c}\operatorname{Re} \text { Berkshire Gas Com- } \\
\text { pany, DPU 11-975 } \\
\text { (December 31, 1956). }\end{array}$ & Normalization A & Deferred Tax Reserve. \\
\hline 49. & & $\begin{array}{l}\text { Boston Edison Company, } \\
\text { CCH UTr. REP. } \\
\text { 18438 (August 14, } \\
\text { 1959). }\end{array}$ & Normalization $\mathrm{R}$ & \\
\hline 50. & Michigan & $\begin{array}{l}R e \text { Detroit Edison Com- } \\
\text { pany, D-1282-A-54.2 } \\
\text { (November 5, 1954). }\end{array}$ & Normalization A & Deferred Tax Reserve. \\
\hline 51. & & $\begin{array}{l}R e \text { Indiana \& Michigan } \\
\text { Electric Company, } 11 \\
\text { P.U.R.3d } 470 \text { (1955). }\end{array}$ & Normalization A & Restricted surplus. \\
\hline
\end{tabular}




\begin{tabular}{|c|c|c|c|c|}
\hline $\begin{array}{c}\text { Item } \\
\text { No. }\end{array}$ & Commission & Decision & $\begin{array}{l}\text { Normalization } \\
\text { or Flow-through }\end{array}$ & Comments \\
\hline 52. & & $\begin{array}{l}\text { Re Michigan Consolidat- } \\
\text { ed Gas Company, 22 } \\
\text { P.U.R.3d } 369(1958), \\
\text { aff'd on rehearing, D- } \\
\text { 3430-59.2 (April 3, } \\
\text { 1959). }\end{array}$ & Normalization $\mathrm{R}$ & $\begin{array}{l}\text { The reserve for deferred } \\
\text { taxes was treated as in- } \\
\text { terest-free capital in } \\
\text { computing the cost of } \\
\text { capital. }\end{array}$ \\
\hline 53. & & $\begin{array}{l}\text { Re Consumers Power Co., } \\
\text { D-2916-59.2 (May 22, } \\
\text { 1959), leave to appeal } \\
\text { denied by Michigan Su- } \\
\text { preme Court (July 27, } \\
\text { 1959). }\end{array}$ & Normalization $\mathrm{R}$ & $\begin{array}{l}\text { Consideration was given } \\
\text { to amount of interest- } \\
\text { free capital available in } \\
\text { arriving at rate of re- } \\
\text { turn. }\end{array}$ \\
\hline 54. & Minnesota & $\begin{array}{l}\text { Re Minnesota Communi- } \\
\text { ty Telephone Company } \\
\text { (November 7, 1955) } \\
\text { and Fairmont Tele- } \\
\text { phone Company (No- } \\
\text { vember } 8,1955 \text { ). }\end{array}$ & Normalization A & $\begin{array}{l}\text { Company has written let- } \\
\text { ters to the Commission } \\
\text { advising the Commis- } \\
\text { sion of accounting being } \\
\text { followed. No adverse re- } \\
\text { ply has been received. }\end{array}$ \\
\hline 55. & Mississippi & $\begin{array}{l}\text { Mississippi Power Co., } \\
\text { Letters from Mississip- } \\
\text { pi P.U.C. to F.P.C. }\end{array}$ & Normalization & $\begin{array}{l}\text { Company allowed to fol- } \\
\text { low FPC accounting in } \\
\text { all respects. }\end{array}$ \\
\hline 56. & Missouri & $\begin{array}{l}\text { Empire District Electric } \\
\text { Co., 22 P.U.R.3d } 399 \\
\text { (1958). }\end{array}$ & Flow-through $\mathrm{R}$ & $\begin{array}{l}\text { The Kansas Commission, } \\
\text { which sat jointly with } \\
\text { the Missouri Commis- } \\
\text { sion in this case, adopt- } \\
\text { ed normalization in fix- } \\
\text { ing the company's Kan- } \\
\text { sas rates. }\end{array}$ \\
\hline 57. & & $\begin{array}{l}\text { Re Raytown Water Com- } \\
\text { pany, Case No. 13,773 } \\
\text { (1958). }\end{array}$ & $\begin{array}{l}\text { Actual straight- } \\
\text { line taxes } R\end{array}$ & $\begin{array}{l}\text { Commission allowed nor- } \\
\text { malization since Ray- } \\
\text { town announced it in- } \\
\text { tended to abandon ac- } \\
\text { celerated depreciation. }\end{array}$ \\
\hline 58. & & $\begin{array}{l}R e \text { Union Electric Com- } \\
\text { pany, 25 P.U.R.3d 125 } \\
\text { (1958). }\end{array}$ & Flow-through A & $\begin{array}{l}\text { In revoking its prior ac- } \\
\text { counting order provid- } \\
\text { ing for normalization, } \\
\text { the Commission pointed } \\
\text { out that the accounting } \\
\text { treatment should be con- } \\
\text { sistent with the Com- } \\
\text { mission's rate-making } \\
\text { policy. In this connec- } \\
\text { tion, the Commission } \\
\text { emphasized that by go- } \\
\text { ing to flow-through ac- } \\
\text { counting there would be } \\
\text { a matching of current } \\
\text { expenses with current } \\
\text { revenues and cited with } \\
\text { approval paragraph } 8 \text { of } \\
\text { Accounting Research } \\
\text { Bulletin } 44 \text { (Revised). }\end{array}$ \\
\hline 59. & & $\begin{array}{l}\text { Case No. } 10723 \text {, in the } \\
\text { matter of general or- } \\
\text { der No. 38-A. }\end{array}$ & & $\begin{array}{l}\text { Companies permitted to } \\
\text { follow either flow- } \\
\text { through or normaliza- } \\
\text { tion for accounting pur- } \\
\text { poses, as of January 1, } \\
1961 \text {. }\end{array}$ \\
\hline 60. & Montana & $\begin{array}{l}\text { Re Mountain States Tel. } \\
\text { \& Tel. Company, 23 } \\
\text { P.U.R.3d } 233 \text { (1958). }\end{array}$ & $\begin{array}{l}\text { Actual straight- } \\
\text { line taxes } R\end{array}$ & $\begin{array}{l}\text { Commission stated that } \\
\text { the company should re- } \\
\text { examine its position of } \\
\text { not taking accelerated } \\
\text { depreciation. }\end{array}$ \\
\hline
\end{tabular}




\begin{tabular}{|c|c|c|c|c|}
\hline $\begin{array}{l}\text { Item } \\
\text { No. }\end{array}$ & Commission & Decision & $\begin{array}{l}\text { Normalization } \\
\text { or Flow-through }\end{array}$ & Comments \\
\hline 61. & Nebraska & $\begin{array}{l}\text { Nebraska Continental } \\
\text { Telephone Company } \\
\text { (November 23, 1955) } \\
\text { and United Telephone } \\
\text { Company of the West } \\
\text { (March 20, 1958). }\end{array}$ & Normalization $\mathrm{R}$ & $\begin{array}{l}\text { Nebraska Continental Tel- } \\
\text { ephone Company has } \\
\text { written letters to the } \\
\text { Commission of account- } \\
\text { ing being followed. No } \\
\text { adverse reply has been } \\
\text { received. }\end{array}$ \\
\hline 62. & Nevada & $\begin{array}{l}\text { Re Southern Nevada } \\
\text { Power Company, L \& S } \\
\text { Dkt. 195 (March 20, } \\
\text { 1958). }\end{array}$ & Normalization $\mathrm{R}$ & $\begin{array}{l}\text { There was no discussion of } \\
\text { normalization in the } \\
\text { opinion but there was } \\
\text { appended, and referred } \\
\text { to in the opinion, a } \\
\text { tabulation which indi- } \\
\text { cated the Commission } \\
\text { allowed deferred taxes. } \\
\text { There was, however, no } \\
\text { specific indication as to } \\
\text { the treatment of the re- } \\
\text { serve. }\end{array}$ \\
\hline 63. & $\begin{array}{c}\text { New Hamp- } \\
\text { shire }\end{array}$ & $\begin{array}{l}\text { Re Public Service Com- } \\
\text { pany of New Hamp- } \\
\text { shire, 18 P.U.R.3d 523 } \\
\text { (1957). }\end{array}$ & $\begin{array}{l}\text { Flow-through } \\
\text { A \& R }\end{array}$ & $\begin{array}{l}\text { Company and Commission } \\
\text { agreed as to flow-through } \\
\text { treatment for rate pur- } \\
\text { poses. Commission si- } \\
\text { multaneously issued Or- } \\
\text { der No. } 6971 \text { revoking } \\
\text { earlier accounting Order } \\
\text { No. } 6756 \text { as to accelera- } \\
\text { ted depreciation but con- } \\
\text { tinued normalization as } \\
\text { to amortization. }\end{array}$ \\
\hline 64. & & $\begin{array}{c}R e \text { New England Tel. \& } \\
\text { Tel. Company, 21 } \\
\text { P.U.R.3d 195 (1957). }\end{array}$ & $\begin{array}{l}\text { Actual straight- } \\
\text { line taxes } R\end{array}$ & $\begin{array}{l}\text { The Company was not } \\
\text { taking accelerated de- } \\
\text { preciation. Commission, } \\
\text { nevertheless, held that } \\
\text { an expense lawfully in- } \\
\text { curred may not be dis- } \\
\text { allowed unless abuse of } \\
\text { discretion is shown. }\end{array}$ \\
\hline 65. & New Jersey & $\begin{array}{l}\text { Re Public Service Elec- } \\
\text { tric \& Gas Company, } \\
\text { Letter order, dated De- } \\
\text { cember } 8,1955 .\end{array}$ & Normalization A & $\begin{array}{l}\text { Tentative decision author- } \\
\text { izing Restricted Surplus } \\
\text { Accounting. }\end{array}$ \\
\hline 66. & & $\begin{array}{l}\text { Plainfield-Ưnion Water } \\
\text { Co., Dkt. 10538 } \\
\text { (August 26, 1958), up- } \\
\text { held by New Jersey Su- } \\
\text { perior Court, 30 } \\
\text { P.U.R.3d } 513(1959) .\end{array}$ & Flow-through $\mathrm{R}$ & $\begin{array}{l}\text { The New Jersey Superior } \\
\text { Court said that they } \\
\text { could not say that the } \\
\text { Commission's action in } \\
\text { following flow-through } \\
\text { was unreasonable. }\end{array}$ \\
\hline 67. & & $\begin{array}{l}R e \text { Hackensack Water } \\
\text { Company, Dkt. No. } \\
9473 \text { (August } 27 \text {, } \\
\text { 1958), upheld by New } \\
\text { Jersey Superior Court, } \\
\text { 30 P.U.R.3d } 526 \\
\text { (1959). }\end{array}$ & Flow-through $\mathrm{R}$ & $\begin{array}{l}\text { In this case the New Jer- } \\
\text { sey Superior Court said, } \\
\text { "This is clearly a situa- } \\
\text { tion where proper defer- } \\
\text { ence must be accorded } \\
\text { to the judgment of those } \\
\text { trained in the field of } \\
\text { public utility regula- } \\
\text { tion." }\end{array}$ \\
\hline 68. & New Mexico & $\begin{array}{l}\text { General Telephone Co. of } \\
\text { the Southwest, } 14 \\
\text { P.U.R.3d } 243 \text { (Cor- } \\
\text { poration Commission, } \\
\text { 1956). }\end{array}$ & $\begin{array}{l}\text { Normalization } \\
\text { A \& R }\end{array}$ & $\begin{array}{l}\text { Deferred Tax Reserve. } \\
\text { Corporation Commis- } \\
\text { sion has jurisdiction over } \\
\text { telephone companies. }\end{array}$ \\
\hline 69. & & $\begin{array}{l}\text { Lea County Gas Co., 10 } \\
\text { P.U.R.3d } 279 \text { (Public } \\
\text { Service Commission, } \\
\text { 1955). }\end{array}$ & Flow-through $\mathrm{R}$ & $\begin{array}{l}\text { Public Service Commis- } \\
\text { sion has jurisdiction over } \\
\text { electric and gas com- } \\
\text { panies. }\end{array}$ \\
\hline
\end{tabular}


APPENDIX-Continued

\begin{tabular}{|c|c|c|c|c|}
\hline $\begin{array}{l}\text { Item } \\
\text { No. }\end{array}$ & Commission & Decision & $\begin{array}{l}\text { Normalization } \\
\text { or Flow-through }\end{array}$ & Comments \\
\hline 70. & New York & $\begin{array}{l}R e \text { Central Hudson Gas } \\
\text { and Electric Corpora- } \\
\text { tion, 28 P.U.R.3d } 317 \\
(1959) .\end{array}$ & $\begin{array}{c}\text { Modified Flow- } \\
\text { through (With } \\
\text { Modification of } \\
\text { Rate of Re- } \\
\text { turn) } R\end{array}$ & $\begin{array}{l}\text { The company's proposal } \\
\text { to normalize was reject- } \\
\text { ed. The opinion holds, } \\
\text { however, that for equi- } \\
\text { table treatment there } \\
\text { should be a sharing of } \\
\text { section } 167 \text { tax benefits } \\
\text { between the company } \\
\text { and customers, with the } \\
\text { customers getting the } \\
\text { major part. The opinion } \\
\text { contains many quota- } \\
\text { tions from the General } \\
\text { Statement of Policy, in- } \\
\text { cluding the statement } \\
\text { "that in going to an ac- } \\
\text { tual tax basis some mod- } \\
\text { ification of the rate of } \\
\text { return" will be neces- } \\
\text { sary. Allowed rate of re- } \\
\text { turn was set at between } \\
6.3 \text { per cent and } 6.4 \text { per } \\
\text { cent. }\end{array}$ \\
\hline 71. & & $\begin{array}{l}\text { Re Niagara Mohawk } \\
\text { Power Corporation, } \\
\text { Case } 19037 \text { (May 26, } \\
\text { 1959). }\end{array}$ & $\begin{array}{l}\text { Modified Flow- } \\
\text { through A }\end{array}$ & \\
\hline 72. & $\begin{array}{l}\text { North Caro- } \\
\text { lina }\end{array}$ & $\begin{array}{l}R e \text { Piedmont Natural } \\
\text { Gas Company, 34 } \\
\text { P.U.R.3d 1 (1960). }\end{array}$ & $\begin{array}{l}\text { Actual straight- } \\
\text { line taxes } R\end{array}$ & $\begin{array}{l}\text { Company had claimed ac- } \\
\text { celerated depreciation } \\
\text { at one time but reverted } \\
\text { to straight-line depre- } \\
\text { ciation. Commission } \\
\text { said that this was a de- } \\
\text { cision within manage- } \\
\text { ment's discretion and } \\
\text { went on to say that the } \\
\text { question of liberalized } \\
\text { depreciation and its rate- } \\
\text { making by-products re- } \\
\text { mains for broader study } \\
\text { than permitted by this } \\
\text { case. }\end{array}$ \\
\hline 73. & & $\begin{array}{l}\text { Re Public Service of } \\
\text { North Carolina, 33 } \\
\text { P.U.R.3d } 398 \text { (1960). }\end{array}$ & Flow-through $\mathrm{R}$ & $\begin{array}{l}\text { With respect to acceler- } \\
\text { ated depreciation the } \\
\text { Commission said it has } \\
\text { not allowed, and will not } \\
\text { here allow, treatment of } \\
\text { income taxes as an oper- } \\
\text { ating revenue deduction } \\
\text { in an amount greater } \\
\text { than the amount actu- } \\
\text { ally paid or payable. } \\
\text { The Commission is pres- } \\
\text { ently making a general } \\
\text { investigation of the sub- } \\
\text { ject as it applies to all } \\
\text { North Carolina utilities }\end{array}$ \\
\hline 74. & $\begin{array}{l}\text { North Da- } \\
\text { kota }\end{array}$ & $\begin{array}{l}\text { Re Montana-Dakota } \\
\text { Utilities Company, 22 } \\
\text { P.U.R.3d 505 (1958), } \\
\text { aff'd in part, } 33 \\
\text { P.U.R.3d } 531 \text { (1960). }\end{array}$ & Flow-through $\mathrm{R}$ & $\begin{array}{l}\text { The North Dakota Su- } \\
\text { preme Court held it was } \\
\text { erroneous to follow flow- } \\
\text { through for section 168, } \\
\text { but permissible to fol- } \\
\text { low flow-through for } \\
\text { section } 167 \text {. }\end{array}$ \\
\hline
\end{tabular}




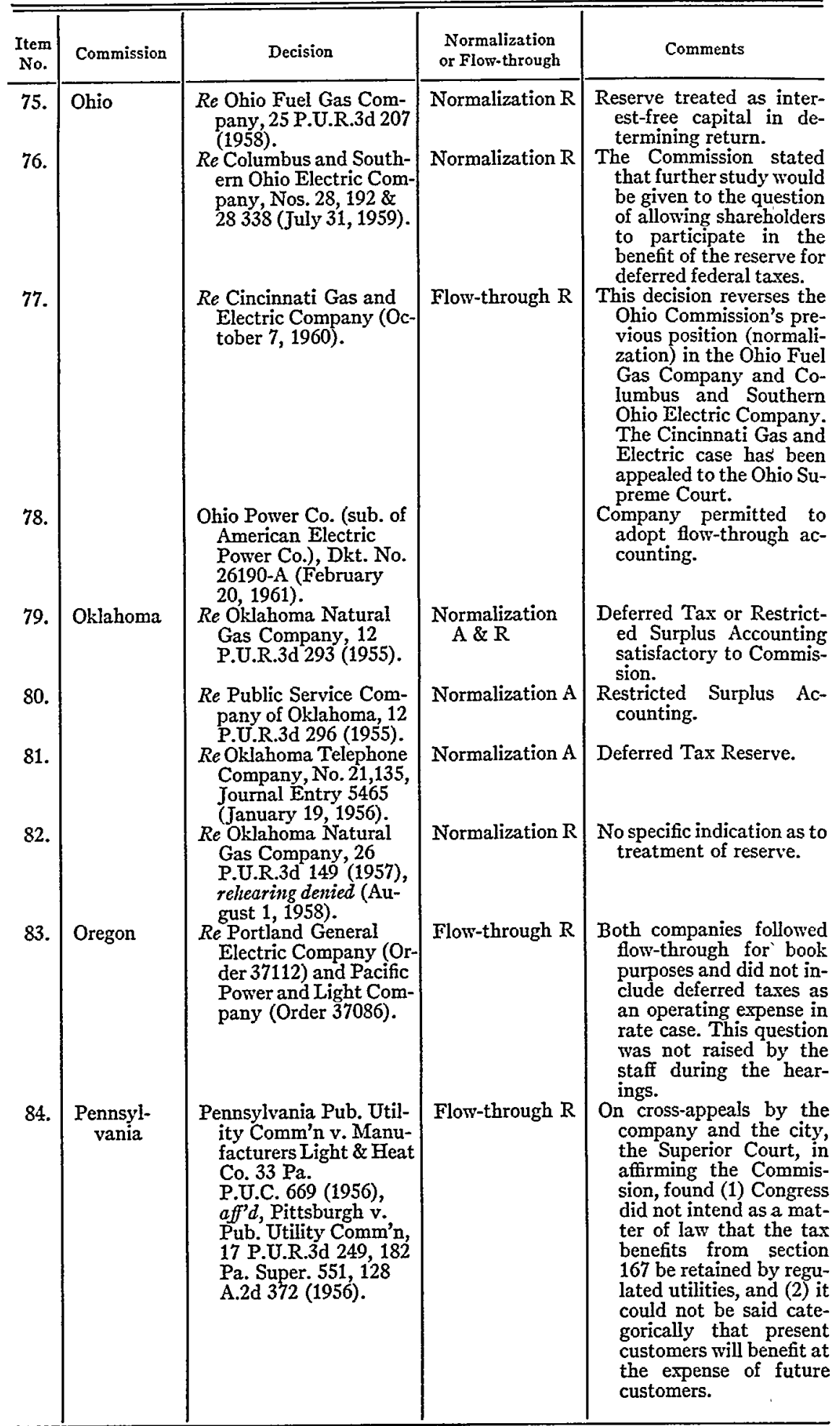




\begin{tabular}{|c|c|c|c|c|}
\hline $\begin{array}{c}\text { Item } \\
\text { No. }\end{array}$ & Commission & Decision & $\begin{array}{l}\text { Normalization } \\
\text { or Flow-through }\end{array}$ & Comments \\
\hline 85. & $\begin{array}{l}\text { South Caro- } \\
\text { lina }\end{array}$ & $\begin{array}{l}\text { Re South Carolina Con- } \\
\text { tinental Telephone } \\
\text { Company, Order } \\
9849, \text { Dkt. } 9710 \text { (Janu- } \\
\text { ary 11, 1956). }\end{array}$ & Normalization A & Deferred Tax Reserve. \\
\hline 86. & & $\begin{array}{l}\text { Re Lockhart Power Com- } \\
\text { pany, Order No. E-772, } \\
\text { Dkt. } 10186 \text { (May 2, } \\
\text { 1957). }\end{array}$ & Normalization A & $\begin{array}{l}\text { Restricted Surplus Ac- } \\
\text { counting. }\end{array}$ \\
\hline 87. & Tennessee & $\begin{array}{c}R e \text { Southern Continental } \\
\text { Telephone Company } \\
\text { (December 30, 1955). }\end{array}$ & Normalization A & \\
\hline 88. & Vermont & $\begin{array}{l}\text { All Utilities, Temporary } \\
\text { Order (February 29, } \\
\text { 1956). }\end{array}$ & Normalization A & $\begin{array}{l}\text { Deferred Tax Reserve; } \\
\text { subsequently rescinded } \\
\text { as to Gas and Electric } \\
\text { Utilities. }\end{array}$ \\
\hline 89. & & $\begin{array}{l}\text { Re Accounting Treat- } \\
\text { ment of Accelerated } \\
\text { Depreciation (Decem- } \\
\text { ber } 3,1958) .\end{array}$ & Flow-through A & $\begin{array}{l}\text { Applicable only to Electric } \\
\text { and Gas Utilities. }\end{array}$ \\
\hline 90. & Virginia & $\begin{array}{l}R e \text { General Telephone } \\
\text { Company of S.E., } 14 \\
\text { P.U.R.3d } 239(1955)\end{array}$ & Normalization A & $\begin{array}{l}\text { Restricted Surplus Ac- } \\
\text { counting. }\end{array}$ \\
\hline 91. & & $\begin{array}{l}\text { Re Eastern Shore Public } \\
\text { Service Company of } \\
\text { Virginia, Case No. } \\
12990 \text { (April 4, 1956). }\end{array}$ & Normalization A & $\begin{array}{l}\text { Restricted Surplus Ac- } \\
\text { counting. }\end{array}$ \\
\hline 92. & Washington & $\begin{array}{l}\text { Re Pacific Power \& Light } \\
\text { Company (Cause No. } \\
\text { U-9097). }\end{array}$ & Flow-through $\mathrm{R}$ & $\begin{array}{l}\text { Company uses flow- } \\
\text { through for account- } \\
\text { ing purposes and neither } \\
\text { company nor staff raised } \\
\text { the question of tax de- } \\
\text { ferral as an operating } \\
\text { expense for rate pur- } \\
\text { poses. }\end{array}$ \\
\hline 93. & $\begin{array}{l}\text { West Vir- } \\
\text { ginia }\end{array}$ & $\begin{array}{l}\text { Re Hope Natural Gas } \\
\text { Company, 23 P.U.R.3d } \\
394 \text { (1958). }\end{array}$ & Flow-through $R$ & \\
\hline 94. & & $\begin{array}{l}\text { Re United Fuel Gas Com- } \\
\text { pany, 27 P.U.R.3d 365 } \\
\text { (1959). }\end{array}$ & Flow-through $\mathrm{R}$ & \\
\hline 95. & & $\begin{array}{l}\text { Re Cumberland \& Alle- } \\
\text { gheny Gas Company, } \\
28 \text { P.U.R.3d } 93 \text { (1959). }\end{array}$ & $\begin{array}{l}\text { Actual straight- } \\
\text { line taxes } R\end{array}$ & $\begin{array}{l}\text { During the hearings the } \\
\text { company informed the } \\
\text { Commission that it was } \\
\text { no longer using acceler- } \\
\text { ated depreciation in so } \\
\text { far as any plant that } \\
\text { would affect West Vir- } \\
\text { ginia was concerned. }\end{array}$ \\
\hline 96. & Wisconsin & $\begin{array}{l}\text { Re Wisconsin Fuel \& } \\
\text { Light Company, 12 } \\
\text { P.U.R.3d 254 (1956). }\end{array}$ & $\begin{array}{l}\text { Normalization } \\
\text { A \& R }\end{array}$ & $\begin{array}{l}\text { Depreciation reserve ac- } \\
\text { counting with reserve } \\
\text { increased by amount of } \\
\text { tax deferred to offset } \\
\text { the accounting for only } \\
\text { actual taxes. The same } \\
\text { treatment was accorded } \\
\text { other utilities in subse- } \\
\text { quent cases. }\end{array}$ \\
\hline 97. & & $\begin{array}{l}\text { LaCrosse Telephone } \\
\text { Corp., 20 P.U.R.3d } 94 \\
\text { (1957). }\end{array}$ & $\begin{array}{l}\text { Normalization } \\
\quad \text { A \& R }\end{array}$ & \\
\hline 98. & Wyoming & $\begin{array}{l}R e \text { United Telephone } \\
\text { Company of West, } 23 \\
\text { P.U.R.3d } 68 \text { (1958). }\end{array}$ & Normalization $\mathrm{R}$ & $\begin{array}{l}\text { No specific indication as to } \\
\text { treatment of reserve. }\end{array}$ \\
\hline 99. & & $\begin{array}{c}\text { Re Black Hills Power and } \\
\text { Light Company, 26 } \\
\text { P.U.R.3d } 598 \text { (1959). }\end{array}$ & Normalization $\mathbf{R}$ & $\begin{array}{l}\text { No specific indication as to } \\
\text { treatment of reserve. }\end{array}$ \\
\hline
\end{tabular}

